\title{
Role of References in Business Marketing- Towards a Normative Theory of Referencing
}

\author{
Risto T. Salminen \\ Kristian Möller
}

\begin{abstract}
Utilization of references is a common marketing practice in business marketing. The globalization of the economy is enhancing the relevance of referencing behavior further, as many SME firms try to overcome the liability of anonymity in new overseas markets. However, there is very little reported academic research on references, their creation, use, effectiveness, or even what kind of activities and customer relationships can be considered to be references. We address this gap by developing a conceptual framework identifying the key modes of using references in business marketing and the factors influencing the need and relevance of referencing. The study starts with a description of the use of references in public procurement processes, followed by a discussion of reference practices identified in marketing textbooks, and an extensive review of the treatment of references in scientific marketing literature. Based on this material, a conceptual framework model of referencing is proposed defining the tasks assigned to references and the kind of contexts where they are primarily employed. The study concludes with a discussion of the theoretical and managerial implications, and a suggestion for a future research for referencing in global economy. [Article copies available for a fee from The Haworth Document Delivery Service: 1-800-HAWORTH. E-mail
\end{abstract}

Professor Risto T. Salminen is affiliated with Lappeenranta University of Technology, Department of Industrial Engineering and Management, P.O. Box 20, FIN-53851 Lappeenranta, Finland (E-mail: risto.salminen@lut.fi).

Professor Kristian Möller is affiliated with Helsinki School of Economics, P.O. Box 1210, FIN-00101 Helsinki, Finland (E-mail: moller@hkkk.fin).

Journal of Business-to-Business Marketing, Vol. 13(1) 2006

Available online at http://www.haworthpress.com/web/JBBM

(C) 2006 by The Haworth Press, Inc. All rights reserved.

doi:10.1300/J033v13n01_01 
address: <docdelivery@haworthpress.com> Website: <http://www.HaworthPress. com> (C) 2006 by The Haworth Press, Inc. All rights reserved.]

KEYWORDS. References, business references, customer references, business marketing, international marketing

\section{INTRODUCTION: REFERENCES IN BUSINESS MARKETING}

This article focuses on the utilization of references in business marketing. We argue that the use of references by business marketers has received only scant research attention and that this phenomenon is theoretically underdeveloped in relation to its managerial relevance in the globalizing economy. Before stating more detailed objectives we will briefly outline the concept of references and referencing behavior.

The idea that references play an important part in business marketing is generally taken for granted. Most issues of business magazines like BusinessWeek, Forbes, and Fortune contain cases on the essential role of references in such strategic actions as launching new products and entering new markets, as well as in enhancing a company's competitive position in the industry. However, there is little reported academic research on references, their creation, use, effectiveness, or even what kind of activities and customer relationships can be considered as references.

Managers generally see successful deliveries of equipment, services, or projects to customers as references (Bird 1992; Hyman 1994; Rosen 1994; Gomes 2003; Wall 2004). These deliveries are often compiled to various types of reference lists that are attached to offers to potential customers. These reference lists are sent to the potential customers in the hope that a positive impression will be conveyed about the supplier and its product/service attributes. A frequently expressed goal is reducing the perceived risk of a potential buyer facing the choice of a new supplier or product by communicating the credibility of the supplier. The importance of specific supplier characteristics and product and technology attributes is reflected in the utilization of different types of reference lists: application segment specific lists, product specific lists, technology specific lists, and country/region specific lists. In brief, major deliveries are often considered as references in business marketing practice. In addition to specific deliveries, the names of existing customers are considered and used as references. A supplier can utilize its 
references in various ways through reference lists (Usunier 1996; Payne et al. 1996), articles in trade journals (Brierty et al. 1998), press releases (Bradley 1995), reference visits (Jackson 1985; Hutt and Speh 1992), promotional material (Hanan 1995), seminars (Hutt and Speh 1992), and the Internet (Ford et al. 2003; Fletcher et al. 2004).

There are several trends that we believe to enhance the importance of referencing and the capability of firms to utilize references in a strategic manner. The intensifying technological complexity, high knowledge intensity, and systemic quality characterize the offerings and production systems of today's industries (Doz et al. 2001; Christensen 2003; Vargo and Lusch 2004a). These characteristics, together with the shortening of technological life cycles (Moore 1999, 2002), encompass a high level of technological and market uncertainty (Moriarty and Kosnik 1989). Another trend is the rapid globalization of most high tech industries. Companies are increasingly operating in a global arena, where they have to be able to convince new customers from different cultural backgrounds about the reliability of their offerings, their delivery and continuous performance (Wolf 2004). Finally, the Internet can be used to establish direct contact over a widely dispersed set of customers. Dell Computer's well-documented direct marketing experience shows how the clever use of an interactive electronic channel allows an industrial marketer to bypass traditional distributors (Dell and Fredman 2000). This presumes, however, that the buying company can be certain about the performance of both the offering and the marketer.

The trends described above suggest that firms operating in fields characterized by high technological uncertainty and investments, or trying to enter markets where they do not have established reputation, need to be able to create references and utilize them efficiently in their marketing. This calls for a normative theory of reference utilization, or referencing for short.

A preliminary scanning through the organizational buying research tradition, business marketing studies, including both strategic aspects and marketing communication research, and the relationship marketing literature revealed only scattered, pragmatically oriented notions and examples about the usefulness of references in different marketing contexts. The organizational buying behavior tradition provides, nevertheless, many useful suggestions by examining sources influencing buyers' perceived uncertainty and discussing the decision criteria buyers employ in different purchasing contexts (Möller and Laaksonen 1986; McQuiston 1989; Bunn 1993). These findings have not, however, been developed into any comprehensive and systematic conceptual 
framework or theory that would explain the utilization of references and the suppliers' reference behavior in business marketing.

Recognizing the gap between the presumed managerial relevance of references and their limited theoretical treatment in business marketing research and literature, the basic objective of this study is to propose a preliminary theory of business marketers' referencing behavior. The development of a conceptual framework identifying the potential modes of references in business marketing and the functions they play has a key role in this quest. We need to identify what kinds of contents have been given to references in which kind of contexts.

We pursue our aim through an extensive literature analysis covering the reference practices identified in the public procurement processes (section three), in the marketing textbooks (section four) and in the scientific marketing literature (section five). On the basis of this material, we propose in section six a conceptual framework for a model of suppliers' referencing behavior, which defines the tasks assigned to references and the kind of contexts they are primarily employed in. The study concludes with a discussion of theoretical and managerial implications, and a suggestion for future research for referencing in global economy. Before commencing the literature analysis, we will briefly discuss the methodological solutions guiding the literature research.

\section{THE CONCEPT OF REFERENCE AND THE STRATEGY OF LITERATURE ANALYSIS}

Carrying out a literature search on a vaguely defined phenomenon contains many problems and choices. First, what key words to use? If only the term reference(s) were used, many relevant studies dealing with the phenomenon but not using the key term might be missed. How then to identify the terms or concepts that are linked to references and their use? It seems evident that a preliminary definition of the target phenomenon laying out its content is needed in order to be able to carry out the search. Second, what managerial and research domains to include in the search and what sources to use to cover the chosen domains?

In order to solve the identified problems in the literature search, a preliminary definition of references was created. In dictionary definitions a reference is generally described as a statement of a person's or object's characteristics (Pickett 2000; Miller 2005). A reference can also refer to a person willing to make this kind of statement (Pickett 
2000). In a similar vein, the act of referring means "tracing or ascribing to a person or thing as cause or source" (Simpson and Weiner 1989). These linguistic definitions clearly support the dominant discussion of references in managerially oriented magazines, which use such terms as "customer references," "supplier references," "client references," and "user references." This usage generally also assumes a causal relation between the established "reference"-a gained customer for exampleand some capability of the supplier.

A look into business dictionaries revealed only a few definitions of references. These were all context-specific, suggesting how a reference can be utilized (Greener 1988; Hart and Hart 1994) rather than explaining what a reference conceptually is. In this sense these definitions are operational definitions, based on context-specific examples and focusing on the potential positive outcomes of references rather than the so-called nominal definitions (Zaltman et al. 1973, 26). What we need, however, is a proposal for a concept that captures the essence of the phenomenon in a generic fashion. In order to be able to develop a theory of reference utilization we have to be able to distinguish its antecedents and consequences or outcomes from the core phenomenon itself.

The use of references in the managerial discussion, the dictionary definitions, and the preliminary skimming of marketing text books led to the following definition of reference: "An indirect proof, based on some practical or concrete evidence, like product, service or systems delivery, of a supplier's capability of delivery." This definition provided the basis for our literature search. What, however, if there exists only limited discussion using the term reference directly? In order to broaden the scope of the search we extended the domain of interest to cover discussions that could have a potential linkage to references and their utilization. Employing again preliminary scanning of business magazines and marketing texts, the following sub-domains were identified: managing perceived risk in business marketing, creating and enhancing supplier credibility through marketing communication, and creating and maintaining trusting business relationships. These extensions widened the literature analysis considerably, but we preferred a conservative search strategy. This is essential, as in delineating the core content and boundaries of any vaguely defined phenomenon, a key approach is to look for concepts that capture closely related phenomena.

In order to manage the scope of the literature analysis, two guiding principles were adopted: (1) those sources that do not literally use the word "reference" will be included only if they are clearly related to the use of references, (2) a hierarchical search starting with as concrete and 
descriptive discussion of references as possible is utilized. The latter heuristic was expected to provide us with a continuously sharpening view of the modes of references and the contexts where they are used. Three types of relevant literature containing information of references and their use were identified: (1) institutional authorities' public rules of procurement, (2) marketing and organizational buying textbooks, and (3) scientific marketing literature.

The sources used in each search are described in the beginning of each section below. The analysis of the material followed a few simple guidelines. First, the different tasks or functions that were assigned to reference(s) were identified. Then the contents given to references in each discussion/literature were interpreted by identifying the relationships between reference and close concepts like establishing credibility, reducing perceived risk, etc. Finally, the context where references were suggested to play a role, like entering a new market, launching a new product type, and influencing a specific potential or existing customer, was identified.

\section{THE ROLE OF REFERENCES IN PUBLIC PROCUREMENT PROCESSES}

The analysis of the role references in the public procurement process was done through the procurement rules of three major public institutions: (1) the European Community (E.C.), (2) the World Bank, and (3) NASA. These were seen to provide a wide enough coverage of major public authorities. Table I describes their published procurement rules.

There are two stages in the procurement procedure, where references seem to be important for the supplier and the buyer: the prequalification stage and the final selection of the supplier.

At the prequalification stage it is important for a supplier not to become dropped out from the group of accepted suppliers to bid. Therefore, the supplier should furnish its offer with evidence from his experience (of works, services, and contracts) from the past 3 to 5 years to prove his past performance, i.e., at least satisfactory level of needed skills and characteristics for the job under procurement. Both general and specific experience is taken into account. The judgement of various attributes takes place on the basis of the extent and performance of both general and particular experience. Performance and experience are used as surrogates of certain attributes. 


\section{TABLE I. Comparison of the Procurement Practices of Three Public Authorities}

\begin{tabular}{|c|c|c|c|}
\hline ISSUE & $\begin{array}{l}\text { EC Public works and } \\
\text { services }\end{array}$ & $\begin{array}{l}\text { World Bank } \\
\text { Goods }\end{array}$ & NASA \\
\hline $\begin{array}{l}\text { THRESHOLD } \\
\text { VALUE }\end{array}$ & $\begin{array}{l}\text { EUR } 6.242 .000 \text { (works) } \\
\text { EUR } 249.000 \text { (services) }\end{array}$ & $\begin{array}{l}\text { Large, complex works, } \\
\text { customized equipment }\end{array}$ & \\
\hline $\begin{array}{l}\text { TYPES OF } \\
\text { PROCUREMENT } \\
\text { PROCEDURES }\end{array}$ & $\begin{array}{l}\text { Open procedures } \\
\text { Restricted procedures } \\
\text { Competitive dialogue } \\
\text { Negotiated procedures } \\
\text { Design contests }\end{array}$ & $\begin{array}{l}\text { Open comp. tendering } \\
\text { Selective tendering } \\
\text { Single tendering } \\
\text { Shopping procedures } \\
\text { Local comp. tendering }\end{array}$ & $\begin{array}{l}\text { Procedure: } \\
\text { - evaluation plan } \\
\text { - qualification standard } \\
\text { - request for proposal } \\
\text { - preproposal conference } \\
\text { - oral presentation } \\
\text { - init. + final evaluation }\end{array}$ \\
\hline $\begin{array}{l}\text { PREQUALIFI- } \\
\text { CATION }\end{array}$ & $\begin{array}{l}\text { Official lists of a member } \\
\text { state accepted adapted to } \\
\text { the prequalification }\end{array}$ & $\begin{array}{l}\text { Official lists are not } \\
\text { applied }\end{array}$ & $\begin{array}{l}\text { Source lists + meeting } \\
\text { qualification standards } \\
\text { of NASA }\end{array}$ \\
\hline $\begin{array}{l}\text { Valid time of } \\
\text { experience }\end{array}$ & $\begin{array}{l}5 \text { years (works) } \\
3 \text { years (services) }\end{array}$ & 5 years & 3 years \\
\hline Shortlisting & Min 3-5 bidders & 3...6 (for services) & Not applied as such \\
\hline $\begin{array}{l}\text { Attributes to be } \\
\text { evaluated using } \\
\text { references }\end{array}$ & $\begin{array}{l}\text { Technical and/or } \\
\text { professional capability } \\
\text { (skills, efficiency, } \\
\text { experience, reliability, etc.) }\end{array}$ & $\begin{array}{l}\text { General experience } \\
\text { Particular experience }\end{array}$ & $\begin{array}{l}\text { Past performance and } \\
\text { relevant and other experience }\end{array}$ \\
\hline $\begin{array}{l}\text { Evidence for } \\
\text { prequalification } \\
\text { furnished by }\end{array}$ & $\begin{array}{l}\text { List of works carried out } \\
\text { over the past five years } \\
\text { (three years for services) } \\
\text { with certificates of } \\
\text { satisfactory execution for } \\
\text { the most important works } \\
\text { among other criteria. }\end{array}$ & $\begin{array}{l}\text { Detailed records: } \\
\text { experience, personnel } \\
\text { and equipment } \\
\text { capabilities, financial } \\
\text { position, litigat. history. } \\
\text { For general experience: } \\
\text { average annual turn-over, } \\
\text { annual production rate as } \\
\text { prime contractor of } \\
\text { comparable projects. } \\
\text { For particular experience: } \\
\text { detailed description of all } \\
\text { contracts of a similar } \\
\text { nature and complexity } \\
\text { undertaken during the last } \\
\text { five years. }\end{array}$ & $\begin{array}{l}\text { A list of government contracts } \\
\text { in the past three years } \\
\text { A list of cost over-/underruns } \\
\text { and reasons for them } \\
\text { A record of contract } \\
\text { completions as against } \\
\text { anticipated dates with } \\
\text { explanations } \\
\text { An identification and } \\
\text { explanation of any } \\
\text { terminations for default or } \\
\text { convenience. }\end{array}$ \\
\hline $\begin{array}{l}\text { CRITERIA FOR } \\
\text { FINAL } \\
\text { EVALUATION }\end{array}$ & $\begin{array}{l}\text { a. The most economically } \\
\text { advantageous tender: } \\
\text { quality, price, technical } \\
\text { merit, aestethical and } \\
\text { functional characteristics, } \\
\text { running costs, cost-effec- } \\
\text { tiveness, after-sales } \\
\text { services, technical assis- } \\
\text { tance, delivery date, } \\
\text { delivery period, period of } \\
\text { completion or } \\
\text { b. the lowest price only. }\end{array}$ & $\begin{array}{l}\text { Evaluation factors: Price, } \\
\text { costs of transport, } \\
\text { insurance, payment } \\
\text { schedule, delivery time, } \\
\text { operating costs, efficiency } \\
\text { and compatibility of } \\
\text { equipment, service and } \\
\text { spare parts, training, } \\
\text { safety, and environmental } \\
\text { benefits. }\end{array}$ & $\begin{array}{l}\text { Evaluation factors: mission } \\
\text { suitability, cost, relevant } \\
\text { experience and past } \\
\text { performance in areas of } \\
\text { product quality, meeting } \\
\text { schedules, efficiency in cost } \\
\text { control, accuracy of previous } \\
\text { cost estimates, degree of } \\
\text { cooperation, processing of } \\
\text { changes and compliance with } \\
\text { other contractual provisions, } \\
\text { other considerations. }\end{array}$ \\
\hline
\end{tabular}


The attributes that can be associated with the utilization of references in prequalification vary greatly. An attribute to be evaluated is defined either as "technical/professional capability" (E.C.), "general and particular experience" (World Bank), or "past performance and relevant/ other experience" (NASA). These definitions reflect the confusion over whether references can be used as indicators of experience/past performance only, or as evidence of present (and in the future existing) skills. Basically, this is the question of how to define a reference.

The received view of the role of references in public procurement processes is depicted in Figure 1. In the evaluation phase the buyer uses the reference material that a supplier produces for its past and present "works, services, contracts" to evaluate the supplier's "general" and "particular" experience and "performance." From this material the buyer tries to infer the supplier's future-oriented capabilities in managing successfully the target project. We expect that references have a strong influence on the short-listing or screening of suppliers. Their impact at the final evaluation stage is more difficult to deduce directly from the written rules, but it seems reasonable to assume that if there are 2 to 3 otherwise close candidates, the differences in references can be decisive.

\section{REFERENCES AND REFERENCING IN MARKETING TEXTBOOKS}

In this review we focused on three issues proposed to reflect the suppliers' modes of use of references: fundamental goals related to the utilization of references, practices of utilizing references, and desirable outcomes of the utilization.

Three fundamental goals related to the suppliers' utilization of references were identified: (1) pursue new customers (Hanan et al. 1978, 120; Stewart and Stewart 1984, 80; Jackson 1985, 111; Fisher 1986, 163; Kotler 1988, 217; Smilor 1989, 142; Hutt and Speh 1992, 118; Bradley 1995, 533; Hanan 1995, 175; Bruhn 2003, 254); (2) sell more or new products to existing customers (Hanan et al. 1978, 120; Riggs 1983, 61; Jackson 1985, 111; Christopher et al. 1994, 22; Maister 1996, 258); and (3) focus offers in promising markets (Stewart and Stewart 1984, 217; Cova et al. 2002, 168).

The practices through which a supplier can use references are various, and their utilization depends on the situation of use. Altogether 
FIGURE 1. Role of References in the Public Procurement Process

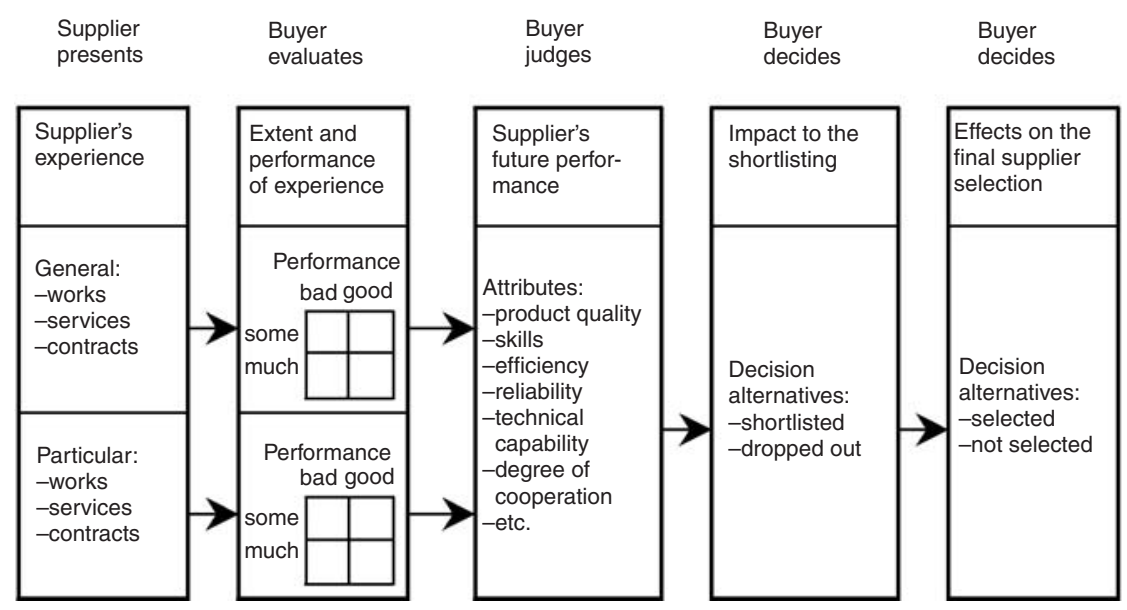

we identified seven practices through which references are communicated.

- Reference visits under various terms like "supplier visits" and "consult with other buyers" (Hutt and Speh 1992, 117), "tour at the showcase site" (Jackson 1985, 111), "personal visits to similar installations" (Hanan et al. 1978, 56), "visits to overseas sites by the buyer's project team" (Cavusgil and Ghauri 1990, 49) seem to be commonly used. This way potential customers can visit reference sites with the supplier's representative, which "can lead to more business from other customers" (Ford et al. 1998, 89).

- Articles in trade journals refer to cases where a successful delivery is described. These cases can be called "success stories" (Smilor 1989,142 ), or "description of the showcase in articles for the relevant trade press" (Jackson 1985, 111). When business buyers read about product applications in an editorial or featured article, "they tend to accept the information as credible and worthy of their consideration" (Brierty et al. 1998, 445).

- Press releases often include news about orders/reorders and are therefore "free publicity" (Bradley 1995, 504).

- Reference lists are generally used together with an offer or proposal. They can be called with many names, for example "customer lists" (McKenna 1986, 77), "listings of the contracts held over the past 
several years" (Stewart and Stewart 1984, 148), or "track record" (Stewart and Stewart 1984, 148; Fisher 1986, 52; Hanan 1995, 175; Payne et al. 1996, 255), "experience record" (Stewart and Stewart 1984, 227), or list of "reference installations" (Bly 1998, 117). Hanan et al. $(1978,120)$ call two databases for referencing purposes "a record of reference" and "a case history testimonial portfolio." Usunier $(1996,507)$ considers reference lists one objective element in the assessment of the credibility of the firm.

- Promotional material includes material supporting sales. It can be for example "brochures" (Fisher 1986, 163; Hutt and Speh 1992, 348), "materials that customers can pass on to noncustomers" (Hutt and Speh 1992, 348), "description of the showcase in sales literature" (Jackson 1985, 111), "a letter from a satisfied customer" (McDonald 1988, 120), "a letter of recommendation from the previous customer" (Stewart and Stewart 1984, 148), and "case histories shown in continuous video formats in trade shows and industry exhibits" (Hanan 1995, 69).

- Seminars can take many forms, for example "management development seminars" (Hutt and Speh 1992, 348).

- The Internet can be used in several ways to inform potential customers of other customers' opinions about the supplier's problem-solving ability. To date customers can hunt for information on solutions to problems from a profusion of sites, and "access the opinions and experiences of their peers in different parts of the world by logging on to bulletin boards and chat rooms" (Ford et al. 2003, 194). References and testimonials from existing customers in the supplier's home page are one way to establish cue-based trust (Fletcher et al. 2004, 132). For customer retention purposes, suppliers provide their customers with an access to online product news and to suppliers' discussion forums (Timmers 2000, 155).

Many desirable outcomes were found in the textbooks. It has to be remembered, however, that the word "reference" is often not used in the normative marketing literature. Instead, the desirable outcomes of using various practices of marketing communication are mentioned in these books. Convincing a buyer about the supplier's competence seems to be an essential objective in competitive bidding (Stewart and Stewart 1984, 148; Fisher 1986; Cova et al. 2002, 212). Establishing reputation (McKenna 1986, 77; Bradley 1995, 533; Kotler 2003, 230) or establish- 
ing credibility (Bradley 1995, 504; Usunier 1996, 507; Bly 1998, 117) are objectives in many contexts.

There is also evidence that the supplier can use the opinions of other buyers as an important risk reduction strategy (Hanan et al. 1978, 53; Puto et al. 1985; Jackson 1985, 167; Hawes and Barnhouse 1987; Mitchell 1989; Hutt and Speh 1992, 117; Mitchell 1998). The perceived risk may depend on product type and the complexity of the product, as perceived risk is mentioned especially in the context of service marketing (Hutt and Speh 1992, 336), systems selling (Hanan et al. 1978, 56), and in the buying of capital equipment (Greatorex et al. 1992; Henthorne et al. 1993).

The textbook view of suppliers' utilization of references is summarized in Table II. It deepens the understanding of references by indicating what purposes references are used (goals) for, through what kind of outcome effects the companies try to reach these goals, and through what practices references are used. It should be noted that the identified goals tell us both about the contexts of use of references and about their functions.

\section{THE ROLE OF REFERENCES IN SCIENTIFIC MARKETING LITERATURE}

The emerging view of references from the marketing textbooks was utilized to guide the exploration of reference practices in the marketing research literature. It is easy to recognize that the identified goals and context of use of references (see Table II) match reasonably well the three traditional Ansoffian growth strategies of a firm; the market penetration strategy, market development strategy and product development strategy (Ansoff 1965). Using Ansoff's growth matrix as a base, we selected nine marketing research traditions or types of literature, which could potentially contribute to reference utilization, and positioned them in appropriate cells, see Table III. Note that the literature positioned in the "market penetration" cell, is relevant for the "market development" and "product development" cells as well. For illustrative reasons, only the additional types of literature related to these two latter cells are presented.

\section{Review Method}

We considered it essential, as pointed out in the methodology discussion, to include sources not mentioning the word "reference" literally in the review, provided that they were clearly related to the phenomenon. 
TABLE II. The View of Marketing Textbooks on the Utilization of References

\begin{tabular}{|l|l|l|}
\hline GOALS & PRACTICES & DESIRABLE OUTCOMES \\
\hline Pursue new customers & Reference visits & $\begin{array}{l}\text { Convincing customer about } \\
\text { competence }\end{array}$ \\
$\begin{array}{l}\text { Sell more or new products to } \\
\text { existing customers } \\
\text { Focus offers in promising } \\
\text { markets }\end{array}$ & Articles & Established credibility \\
& Reference lists & Established reputation \\
& Promotional material & Reduced perceived risk \\
& Seminars & \\
& Internet & \\
\hline
\end{tabular}

TABLE III. Scope of the Review of Scientific Marketing Literature Positioned Along Growth Strategies*

\begin{tabular}{|c|c|c|}
\hline $\begin{array}{l}\text { PRODUCTS } \\
\text { MARKETS }\end{array}$ & PRESENT PRODUCTS & NEW PRODUCTS \\
\hline PRESENT MARKETS & $\begin{array}{l}\text { Market penetration } \\
\text { Increasing market share by winning } \\
\text { new customers or non-users in: } \\
\text { - Relationship marketing } \\
\text { - Project marketing and systems } \\
\text { selling } \\
\text { - Services marketing } \\
\text { - High tech marketing } \\
\text { - Marketing communication } \\
\text { - Sales management } \\
\text { - Key account management }\end{array}$ & $\begin{array}{l}\text { Product development } \\
\text { - Customer involvement in: } \\
\text { Stages of new product } \\
\text { development process }\end{array}$ \\
\hline NEW MARKETS & $\begin{array}{l}\text { Market development } \\
\text { Customer involvement in: } \\
\text { Entry process }\end{array}$ & (Diversification) \\
\hline
\end{tabular}

* Note that the literature positioned in the "market penetration" cell is relevant for the "market development" and "product development" cells as well. For illustrative reasons, only the additional types of literature related to these two latter cells are presented. 
Therefore, over 100 key words/key word combinations were used in the review to find academic literature dealing with references or at least related to references. Academic literature was searched from LINDA (Database of all Finnish scientific libraries) and from all international databases covering marketing studies available through the library of the Helsinki School of Economics. International Dissertation Abstracts of the past 10 years were also reviewed thoroughly. Additionally, the contents of at least the past four years of important international marketing, industrial marketing, and management journals were reviewed thoroughly. The contents of the most important journals were reviewed over a 10-year period. A classification of the reviewed journals is shown in Table IV.

Below, each type of literature is discussed and its contribution to the context of use of references (cells) is evaluated. For the sake of brevity, only short descriptions of the literature can be given. The core contribution of each type of literature is summarized by identifying the key tasks the literature relates to references and by providing a few examples of the utilization of references.

\section{Relationship Marketing}

There are many ways to define the concept of business relationship. One definition for it is "mutually oriented interaction between two re-

TABLE IV. Journals Reviewed in the Search for Articles Related to References

\begin{tabular}{|l|l|}
\hline TYPE OF JOURNAL & NAMES OF JOURNALS \\
\hline Industrial marketing journals & $\begin{array}{l}\text { Industrial Marketing Management, Industrial Marketing and Purchasing, } \\
\text { Journal of Business \& Industrial Marketing, Journal of Business-to-Business } \\
\text { Marketing, Advances in Business Marketing }\end{array}$ \\
\hline Recognized marketing journals & $\begin{array}{l}\text { Journal of Marketing, Journal of Marketing Research, International Journal } \\
\text { of Research in Marketing, Journal of the Academy of Marketing Science, } \\
\text { European Journal of Marketing, Journal of Marketing Management, Journal } \\
\text { of Services Marketing, Journal of Advertising Research, International Mar- } \\
\text { keting Review }\end{array}$ \\
\hline Management journals & $\begin{array}{l}\text { Journal of International Business Studies, Journal of Product Innovation } \\
\text { Management, Journal of Business Research, International Journal of Ser- } \\
\text { vice Industry Management, R\&D Management, Strategic Management Jour- } \\
\text { nal, European Management Journal, Journal of General Management, } \\
\text { Scandinavian Journal of Management, Journal of International Manage- } \\
\text { ment, Journal of Construction Engineering and Management, Management } \\
\text { Decision, Management Science, International Journal of Purchasing and } \\
\text { Materials Management, European Journal of Purchasing and Supply Man- } \\
\text { agement, European Journal of Operational Research, Technovation, Inter- } \\
\text { national Business Review, SLOAN Management Review, California } \\
\text { Management Review, Business Horizons }\end{array}$ \\
\hline
\end{tabular}


ciprocally committed parties" (Håkansson and Snehota 1995, 25). This definition emphasizes a fairly deep relationship between the parties. Dwyer et al. (1987) for their part suggest that the type of relationship is determined by the different amounts of motivational investment that the buyers and sellers are prepared to commit to the relationship. Even if one of the parties has a low motivational investment it does not mean that the parties do not have a relationship-rather that it is a relationship of a specific type. It is reasonable, however, to assume that a good customer relationship is a prerequisite when a supplier wants to utilize its relationships as references (Turnbull 1979; Ford 1984, 70; Cunningham and Culligan 1990, 521).

The quality and strength of a relationship is pronounced, when the relationship is utilized actively, that is, not only as an item in a reference list to potential customers, but in ways where the reference customer is actively involved in the marketing process. A key question in this use context is how relevant or valuable a reference customer relationship is for the "third party," the targeted new customer? A good reference relationship is such that the supplier (and/or the reference customer) is enable to communicate the value of that relationship to the potential customer in a way which the potential customer can evaluate. The potential customer should be able to evaluate the direct and indirect benefits and costs involved in the reference installation or delivery, for perceived value (see Ravald and Grönroos 1996; Möller and Törrönen 2003). This is justified from the potential customer's view, since he has to be able to estimate whether he has interest/resources to invest in the supplier relationship as much as the reference customer has done. This estimation is facilitated when the reference case is similar to the potential need of the target customer, and if the reference customer allows the costs and benefits involved in the case to be examined. These factors influence the potential reference value of any customer relationship.

The use of references in developing a customer relationship can be examined with the help of the concepts of commitment and trust, which Morgan and Hunt (1994) and Halinen (1997) have identified as key mediating variables in relationship marketing. According to this proposition, the antecedents of trust and commitment are factors that should be managed to maintain and develop business relationships.

Commitment can be defined as "an implicit or explicit pledge of relational continuity between the exchange parties" (Dwyer et al. 1987, 19). However, the focus of a customer's commitment may actually vary, and commitment can be regarded as a mix of commitments: to a person, product, supplier, or to a technology (Jackson 1985, 67). When market- 
ing solutions are based on novel technology, the supplier should be able to demonstrate to its old and new customers that a substantial number of credible vendors are going to be committed to that technology (Jackson $1985,84)$. If the supplier has a high market share and strong position in the industry, it might be enough to show the potential customer that a number of the supplier's other customers are getting committed to that technology. If the supplier of the new technology is relatively unknown in the market, potential customers generally request an open inspection possibility of at least one or two well operating reference installations. In this situation the development of trust on the supplier's capability of delivery of a working system and maintaining it is essential.

In winning new customers it is often necessary to break existing supplier relationships. In case the buyer-seller relationship is in a very advanced and committed phase, breaking the relationship is a challenging task (Dwyer et al. 1987, 19). We believe that it is necessary to be able to demonstrate considerably higher customer value than the buyer achieves through the current relationship; see Anderson and Narus (1990) for a discussion on comparison levels. In addition to the basic efficiency of the product/system it is probably necessary, in order to decrease a potential customer's commitment to its present supplier, to be able to demonstrate reasonable switching costs. The buyer's anticipation of high switching costs gives rise to the buyer's interest in maintaining, not breaking a quality relationship (Dwyer et al. 1987, 14). The illustration of switching costs often requires a concrete case example in the form of existing deliveries and customer relationships.

In a nutshell, the relationship marketing literature suggests that the utilization of references has an important role in: (1) winning potential new customers, and (2) breaking ongoing competing supplier relationships.

$\begin{array}{ll}\text { PROPOSED TASK } & \text { REFERENCE UTILIZATION } \\ \begin{array}{l}\text { Winning potential new } \\ \text { customers }\end{array} & \begin{array}{l}\text { Communicating the value of the } \\ \text { relationship during reference visits and in } \\ \text { other ways }\end{array} \\ \begin{array}{l}\text { Breaking competing } \\ \text { supplier relationships }\end{array} & \begin{array}{l}\text { Reduction of commitment to present sup- } \\ \text { plier by demonstrating acceptable switch- } \\ \text { ing costs }\end{array}\end{array}$


CASE SAP: TARGET BASE OF REFERENCES CUSTOMERS OF SAP AND ITS BEST PRACTICE SHOWCASES

"We want to deliver software solutions, and to do that, you need deep applications knowledge as well as applications infrastructure and components," said SAP CEO Henning Kagermann at the company's US user conference in May. SAPs apps infrastructure piece is filled by NetWeaver, which, with the 2004 version launched in March, marks an exciting first step towards SAP's goal of having all its apps retooled to run on NetWeaver by 2007 . Now, SAP is busy building up its target base of 1,000 reference customers for NetWeaver by year's end. With a pool of references in the "low low tens," according to SAP executive board member Shai Agassi in June, SAP is not even halfway there. Then again, with a customer pool of 25,000, SAP has lots to tap into.

SAP also pioneered its shared-services concept in the Asia-Pacific with the establishment of its APA Shared Services Centre (APA SSC) in Singapore in October last year. "The SSC will significantly enhance corporate governance by ensuring more efficient and effective risk management. We will also showcase our best practice learnings to our prospects and customers, so that they, too, can run their businesses efficiently, resulting in stronger profit margins," said Hans-Peter Klaey, SAP Asia-Pacific's president and CEO. (Jorina Chloy: "SAP," Asia Computer Weekly. Singapore: Dec 1, 2004, p. 1).

CASE SIKORSKY: AN IMPORTANT REFERENCE CUSTOMER THROUGH ACCEPTABLE SWITCHING COSTS

Canada's choice of the S-92 for its maritime helicopter gives Sikorsky a long-needed military reference customer, but the jury is still out on whether or not the contract will impact high-profile helo competitions in the U.S. The decision ends a more than 10-year-long saga that included a contract for EH101, which was cancelled by the previous administration. Sikorsky's S-92 bested AgustaWestland's EH101 for the 28-helicopter, \$1.35-billion (C \$1.8-billion) contract (and its \$2.4-billion, 20-year support award). "Sikorsky met all stated requirements of the military and at the lower cost," said Defense Minister Bill Graham. The aircraft will replace Sea Kings and operate from Canadian frigates. (Robert Wall: "Cyclone Forming," Aviation Week \& Space Technology. New York: Aug. 2, 2004, Vol. 161, Iss. 5: p. 33).

\section{Project Marketing and Systems Selling}

Project marketing and systems selling represent research traditions in industrial marketing that pay special attention to the process characteristics of business and to the complexity of products/systems (Günter and Bonaccorsi 1996, 531).

Systems selling can be defined as follows: "systems selling, broadly speaking, means that the seller offers a combination of hardware and software products (including problem solution, service, etc.) that together serve a set of functions in the buying organization" (Mattsson 1973). A buyer's potential loyalty stems from the fact that systems selling increases the switching costs of the customer (Paliwoda and Bonaccorsi 1993, 156). Project marketing, on the other hand, is defined as "a complex transaction covering a discrete package of products, services and other actions designed specifically to create capital assets for 
the buyer within a designated period of time" (Cova and Holstius 1990, $6)$. The basic difference between the concepts of systems selling and project marketing is that one project can include several systems, and thus project marketing has been considered wider in scope than systems selling (Ahmed 1993, 31). Therefore, we could rather speak of "project-and system-based industries" (Günter and Bonaccorsi 1996, 533).

Important features of project marketing are uniqueness (Ahmed 1993, 8; Cova et al. 1993, 376; Cova et al. 1996, 648) and complexity (Mazet and Cova 1992, 241). These result from the need to combine several components for any offer, and from the tailor-made character of each situation. These special features cause many strategic problems to project/system companies. Cova et al. (1993) divide these into (1) discontinuity of demand and (2) the question of to bid or not to bid for a particular project.

Under the conditions of demand discontinuity, there exists the problem of maintaining the internal technological capability in periods of absence of demand, as well as the problem of allocating technical skills to heterogeneous projects over time (Bonaccorsi et al. 1996, 542). In our opinion buyers are generally aware of suppliers' problems in maintaining their technological capability, and that is why they often ask for as recent references as possible.

It has been proposed that successful systems installations can be regarded as self-perpetuating customer relationships, provided that trust and mutual benefit can be maintained (Hannaford 1976, 144). However, long time spans between two projects for one customer may cause significant discontinuity between the buyer and the seller (Cova et al. 1996, 650), causing problems in relationship maintenance and in having credibility in future projects. If the supplier does not succeed in maintaining the relationship, the competition faced in the next tender can be almost as tight as a new selling situation. That is, in "sleeping relationships" (Hadjikhani 1992, 153 and 1993, 6) references are needed to re-establish supplier credibility.

The second problem arising from the special features of systembased business is whether to bid or not to bid in a particular bid. This decision can be evaluated either from a short-term or long-term view, which can be conflicting (Hadjikhani 1993, 2). In the long run the essential problem of a supplier is how to manage the portfolio of projects (Cova et al. 1993). This means that a supplier should not seize all bidding opportunities. Messner (1994) concludes that companies should 
pursue projects where: (1) they are qualified for the project, (2) they are competitive, and (3) the project supports the organization's strategic goals (ibid., 2).

It is not only difficult to evaluate whether to bid, but preparing an offer requires also estimating the resources. Considerable time and effort are usually required to prepare an estimate, with the result that the bid preparation capacity acts as a constraint on the volume of bids submitted (Slatter 1990, 310). In many industries firms face bidding situations in which: (1) the opportunity exists to bid on a given contract; (2) a "follow-on" contract is likely; and (3) the firm winning the initial contract has a substantial advantage in the follow-on contract negotiations (Brooks 1978, 35).

We propose that references can have an important role in the project evaluation process in the phases "assess competitive advantages" and "select projects to pursue" (Messner 1994, 92), as references reflect the experience and capability of the company. A potential bidder can thus evaluate its own and its competitors' relative strengths in a particular project by analyzing each relevant actor's portfolio of references (projects, installations). The buyer is obviously interested in the references for exactly the same reason-references 'operationalize' the strengths and weaknesses of bidders (Ahmad 1990).

In sum, references can be utilized in project/systems-based industries for (1) getting into a new project market, (2) re-establishing credibility among old customers, and (3) analyzing when to bid/not to bid for a particular project.

\section{PROPOSED TASK}

Getting into new project market

Re-establishment of credibility among old customers

Serving as a strategic criterion in bidding decisions

\section{REFERENCE UTILIZATION}

Solid reference needed to demonstrate credibility.

New references needed to re-establish credibility in sleeping relationships.

To aid in bid/not to bid decisions: evaluation of areas of competitive advantage between self and key competitors through analysis of core references. 
CASE CREDIT UNIONS: THE SUPPLIER'S PROJECT CAPABILITY AND COMPONENT SUPPLIERS' REFERENCES

"Your search might turn up an intriguing new technology offered by a start-up company, but if the company doesn't have a proven track record or solid financials, that could pose too big a risk for your credit union," says Steve Williams, principal of Cornerstone Advisors Inc. Scottsdale, Arizona. "Sometimes you can triage based on those factors."

Williams recommends asking this question frequently about every system component and feature. "I can't emphasize enough how important that is in the process because you learn so much by looking at users of products," he says. In other words, ask for references for each major component, not just for the system as a whole. "A crucial issue that really frustrates credit unions is assessing how good the vendor is to work with on a project basis," Williams says. "That's very important, and it's a place where credit unions have had bad luck in the past. They may say, 'Our vendor moves too slowly'." (Karen Bankston: "Smart Shopping," Credit Union Management. Madison: Dec 2003, Vol. 26, Iss. 12; p. 14).

\section{CASE PLANAR: GETTING INTO A NEW MARKET}

Prices of computer monitors, Planar's largest source of revenue, have been steadily falling because of competition from low-cost manufacturers based overseas. Gains in Planar's other businesses only partially offset the declines, so the company said it wants to invest in its growing medical business and in new markets overseas. Planar wants to expand its presence in Asia and Europe, and to improve sales of video screens used in medical equipment. In the long run, Planar also hopes to make a splash in an emerging market for "digital signage," video screens used for retail advertising in public places.

Cherrie Prinz, investment analyst for D.A. Davidson, said that Planar has an uneven track record and that it's difficult to assess the company's likelihood of success. She said Planar has yet to capitalize on a solid opportunity in medical products and hasn't provided enough information for investors to make informed judgments about its prospects in retail advertising. (Mike Rogoway: "Shakeup Replaces Planar Executives," Knight Ridder Tribune Business News. Washington: Apr. 22, 2005 p. 1).

\section{Services Marketing}

It has often been argued that services have four special characteristics or differences compared to goods: intangibility, heterogeneity, inseparability, and perishability (Jackson and Cooper 1988, 113; Parasuraman and Varadarajan 1988, 58; Lee 1989, 295; Jackson et al. 1995, 100; Zeithaml and Bitner 1996, 19). Furthermore, it is claimed that each of these four attributes results in various marketing and buying implications. Recently, some researchers have challenged this view by suggesting that the origin of these special characteristics is the early service researchers' need to contrast services to goods and to their manufacturing perspective, and that in fact these special characteristics are not valid anymore and even prevent the development of marketing theory (Vargo and Lusch 2004b; Lovelock and Gummesson 2004). However, these researchers do not claim that none of these special characteristics ever would apply to any service but that there are sufficient exceptions to discredit the claim of their universal applicability (Lovelock and Gummesson 2004, 31). 
Industrial services can be very complex in character compared to consumer services, which are the object of a majority of service marketing studies. It has been proposed that in buying industrial services it is more difficult to determine quality with services than with goods (Jackson et al. 1995, 100). Because industrial services are heterogeneous across time, organizations, and people, ensuring consistent service quality is often very difficult. In the absence of tangible cues, buyers must depend on other cues in evaluating quality. Therefore, questions like how to communicate quality and value to the customer and how to ensure the delivery of consistent quality service are challenges for a responsible manager.

In the customer acquisition phase of services marketing, the needed personification is achieved through the use of reference customers and other testimonials (Bruhn 2003, 254). In the evaluation of services business, prospective buyers are generally forced to depend on surrogates to assess what they are likely to get (Chisnall 1995, 26). Customer references can be regarded as surrogate measures for service quality. We propose that a supplier should utilize references to signal service quality to potential customers. These, in turn, can utilize references as operationalized evidence in verifying a particular supplier's past/present performance. In sum, the proposed task of references in this context is to signal service quality.

\section{PROPOSED TASK}

Signal service quality to potential customers.

\section{REFERENCE UTILIZATION}

References and third-party referrals can be utilized to influence a potential customer.

CASE EXPERT SERVICES: OVERCOMING THE SELLING PROBLEMS THROUGH REFERENCES

Another way to create tangible reminders of service benefits is to provide prospects with third-party evaluations of your work, including testimonials from clients and industry surveys that rank or rate your company. Third-party evaluations give prospects the objective help they need in deciding whether to work with you. At the same time, your reputation as a professional gains critical mass when it's supported by independent parties who have no vested interest in your firm or bias against it.

Likewise, you can communicate your service benefits swiftly by relating stories and anecdotes about the client experience. Prospects can put their intellectual arms around such stories and remember the information better. If asked to recite a nursery rhyme or favorite story from childhood, most of us can do so with ease. That's the power of stories versus facts.

Put the prospect in the frame. Most sales require numerous interactions prior to closing. So once you've created a colorful picture of your services at the initial presentation, have the prospect talk to present clients for references. This puts him or her right in the picture frame; the prospect can test-drive your services vicariously through another client's experiences. 
Present customers are your best sales tool, because they understand the value of your services firsthand. To set the stage for these references, ask a number of clients whether they would be willing to receive the calls. Select a variety of clients by size, industry, usage or whatever variables pertain to your market. Then, contact the present client before each reference call to explain the prospect's need for your services. It's a good idea to arrange a specific time for the call as well. Many reference calls get hung up in a terminal telephone tag between busy people; your help in setting the appointment cuts through this time waster.

The trip to the "service factory," coupled with reference calls, is far more persuasive than any sales presentation, however polished it may be. Why? Because an independent person speaks about your product (the reference) and prospects get to check their comfort level through personal interactions (the visit). They then have objective advice and real people to use in making a decision in your favor. (Christine Filip: "Selling Expert Air," Small Business Reports. New York: Sep. 1994. Vol. 19, Iss. 9; p. 9).

\section{High Tech Marketing}

High tech marketing, characterized by high market uncertainty and high technical uncertainty, contains unique problems for organizational buyers and marketers alike (Moriarty and Kosnik 1989, 8). From a buyer's perspective the problems existing in high-technology markets are twofold: (1) high technology markets are characterized by considerable uncertainty, in part due to heterogeneous and rapidly changing technologies, and (2) buyers frequently face high switching costs as a result of earlier commitments to particular product technologies or vendors (Heide and Weiss 1995, 30). The general effect of switching costs for a buyer is a disincentive to explore new vendors and therefore "well-established references" are needed (Easingwood and Koustelos 2000, 30). Heide and Weiss $(1995,38)$ have found that the uncertainty generated by the rapid pace of technological change both expands a buyer's information collection effort and restricts the tendency to switch vendors.

It seems that a new marketer of high technology can win customers only in case it can overcome high switching costs, by showing convincing references that prove the advantages of its product and technology. The conclusions made on the basis of relationship marketing are also valid here. We propose that the utilization of references can be used for at least three tasks in the high technology context: (1) the supplier itself can become certain of the functioning of a new product technology only through a "reference installation," (2) the supplier can demonstrate the product technology to the buyer, and (3) to overcome a potential buyer's high switching costs, especially by proving the supplier's capability and commitment to the technology in question (for the last point, see Shaw et al. 1989, 52). 


\section{PROPOSED TASK}

Prove the functionability of the technology to the supplier

Prove the functionability of the technology to the buyer

Overcome the buyer's high switching costs

\section{REFERENCE UTILIZATION}

Due to high technological and market uncertainty, successful references enhance the supplier's own understanding and commitment to its product technology.

Due to high technological uncertainty, successful references are needed to ensure the credibility of the technology to the buyers.

Due to high technological uncertainty, successful references prove the supplier's commitment to the technology, thus reducing psychological switching costs.

CASE INFINITEC: THE FIRST ORDER FOR PHONE SYSTEM PROVING ITS FUNCTIONABILITY TO THE SUPPLIER

Tulsa-based Infinitec Communications has its first production order for the Inteleflex Multi-service Digital Loop Carrier platform system. The order is from Chouteau Telephone in Chouteau. A beta test customer since June, the telephone company has ordered three completed systems to be installed in early 1999.

"Our first production units are on schedule to begin shipments this December and the feedback from our beta unit installations indicates that our new technology is filling a gap in the digital local loop market for a truly multi-service platform," said Ron Waeghe, the Tulsabased company's vice president of sales and marketing. ("Infinitec gets first order for phone system," Journal Record. Oklahoma City, Oklahoma, Oct. 21, 1998 p. 1).

CASE CHASM: PROVING THE FUNCTIONABILITY OF TECHNOLOGY TO BUYERS BY CROSSING THE CHASM BETWEEN EARLY ADOPTERS AND EARLY MAJORITY

When promoters of high-tech products try to make the transition from a market base made up visionary early adopters to penetrate the next adoption segment, the pragmatist early majority, they are effectively operating without a reference base and without a support base within a market that is highly reference-oriented and highly support-oriented. Promoters can adopt either a sales-driven or a reference-driven approach.

The consequences of being sales-driven during the chasm period are, to put it simply, fatal. Here's why: The sole goal of the company during this stage of market development must be to secure a beachhead in a mainstream market-that is, to create a pragmatist customer base that is referenceable, people who can, in turn, provide us access to other mainstream prospects. To capture this reference base, we must ensure that our first set of customers completely satisfy their buying objectives. 
Winning over one or two customers in each of 5 or 10 different segments-the consequence of taking a sales-driven approach-will create no word-of-mouth effect. Your customers may try to start a conversation about you, but there will be no one there to reinforce it. By contrast, winning four or five customers in one segment will create the desired effect. Cross the chasm by targeting a very specific niche market where you can dominate from the outset, force your competitors out of the market niche, and then use it as a base for a broader operations. (Geoffrey A. Moore: "Crossing the Chasm-Marketing and Selling High-Tech Products to Mainstream Customers," revised edition, Harper Business, 1999 , p. 22, 68 and 69).

\section{Marketing Communication}

In examining the relative importance of different modes or channels of persuasion in industrial marketing, Parasuraman $(1981,280)$ found that product and supplier specifications were the most influential factor, followed by personal selling and peer recommendations from other firms on par. Communication of these recommendations can be considered communication by references. The importance of recommendations in industrial marketing comes from the need of trying to reduce the perceived risk. The higher the risk, the more important are not only the references as such, but the credibility of the source (Hutt and Speh 1992, 177).

Slatter $(1987,203)$ found that establishing the firm's credibility was one of the major aspects of sales visits in a purchasing process where competitive bidding was involved. Photographs of reference installations/projects were typically used as an aid in establishing credibility. Alajoutsijärvi and Pento (1991) have examined sales presentations of capital goods to buying centers in international firms. They propose that the focus and way of utilizing reference material should be adapted individually to each member of the decision making unit.

In sum, the industrial marketing communication studies suggest that special attention should be paid to the credibility of the source communicating about the reference. This concerns both the reference itself (if a customer organization) and the media. On the basis of communication theory, we suggest that the media that are perceived as neutral-scientific seminars/conferences, journals and magazines-have a higher credibility potential than advertising or sales representatives. Another result is that the type of reference information communicated should be adapted to match the special interest of each major buying center member.

\section{PROPOSED TASK}

Enhance source credibility and convince a buyer about the product and supplier performance

\section{REFERENCE UTILIZATION}

Select credible references; use credible media; match reference material per target persons in the DMUs. 


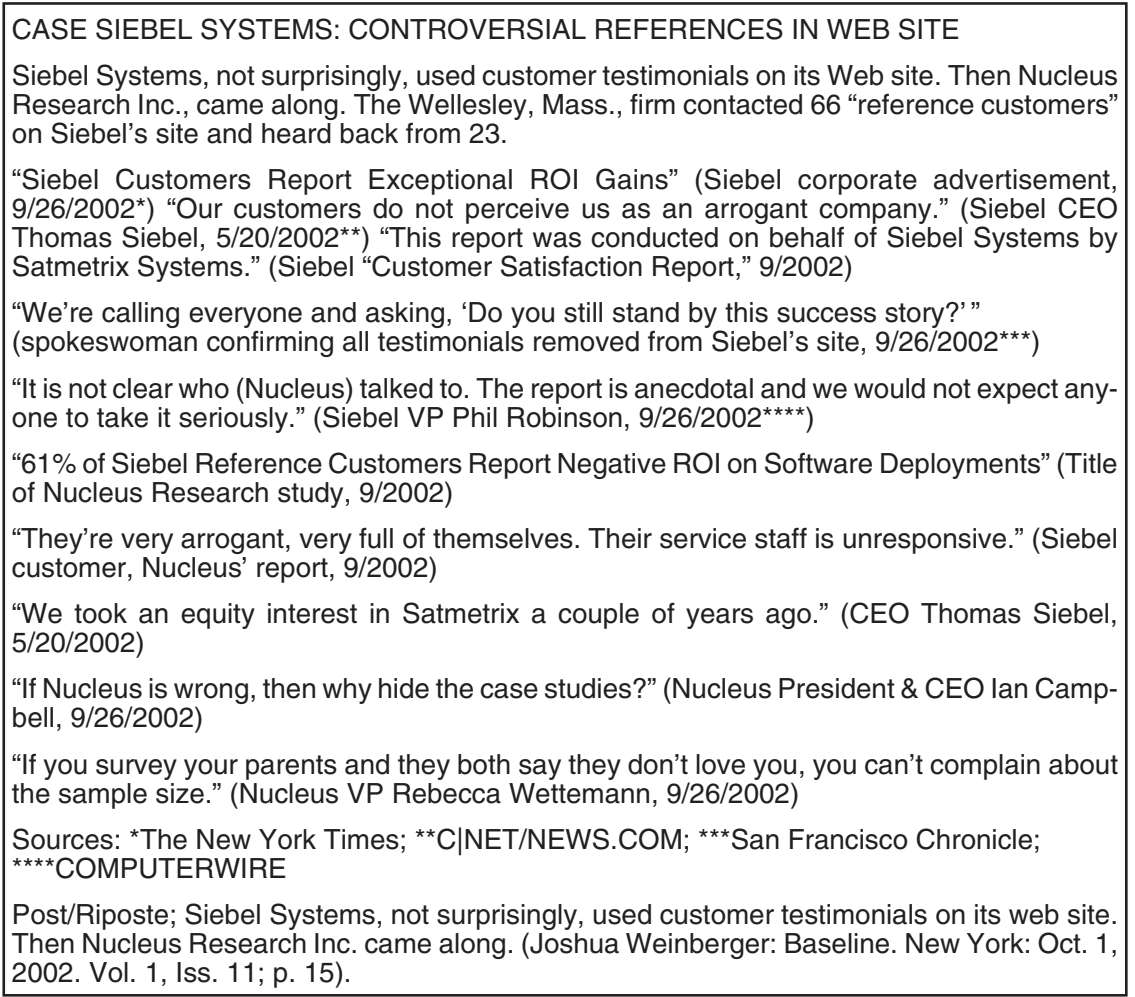

\section{Sales Management}

Sales management has generally been ascribed six tasks: recruiting, training, motivating, supervising, evaluating and controlling the sales force (Hutt and Speh 1992, 503). Professional selling skills should be developed in the industrial sales force. The elements of these skills include, among other things, "thorough knowledge of products and their applications in specific industries; the ability to diagnose customers' problems and to offer acceptable solutions in terms of the products being offered to sale" (Chisnall 1995, 421). Training is especially important in professional selling, where the sales representatives must be problem solvers, discoverers of needs, negotiators, and developers of positive relationships with customers (Peterson 1990, 196).

Several sources emphasize the usefulness of real customer applications in the training of sales representatives (Deutscher et al. 1982, 177; 
Johnston and Boles 1994). As a conclusion, utilizing reference applications in sales training is evidently an important internal use of references.

\section{PROPOSED TASK}

Improve sales force performance through realistic training.

\section{REFERENCE UTILIZATION}

Using reference applications in sales force training.

CASE EQUIPMENT SUPPLIER FOR PROCESS INDUSTRY: REFERENCE APPLICATIONS IN SALES TRAINING

Comment of a CEO of a medium-sized international process equipment supplier: "When a salesperson knows that s/he will be presenting a customer case of an application reference at a coming sales meeting of the company, s/he will study all the relevant aspects of that process application. The presentation will be then used for training purposes for all the sales people attending the meeting.

And naturally this forces us to do our homework properly, in other words if a person knows that $\mathrm{s} / \mathrm{h}$ e will give a presentation in October 2005, s/he puts his efforts on the matter and finds out thoroughly how things are in reality. Otherwise it will a bit too superficial in this sales and marketing business, that is, is based on beliefs and suppositions."

\section{Key Account Management}

Key account management is based on recognition of the different needs and potential of business customers. The importance of a customer can be measured by the volume of the customer (Cardozo et al. 1988), or more broadly, by the strategic importance of the customer (Pels 1992, 6; Millman and Wilson 1995, 1668; Pardo et al. 1995, 124). Conceptually, we can differentiate between "main clients" (high-volume) and "key clients" (having strategic importance) by considering key clients as "those customers who assist the selling firm's development and help it to be more competitive" (Pels 1992, 6).

To be able to manage key customers, they have to be identified first. The criteria for selecting key customers vary in the literature due to the varying nature of the strategic importance of customers (Pardo et al. 1995, 124; Ojasalo 2001, 204). For a recent review and integrative conceptualization of key account management, see Homburg et al. (2002). On the basis of the literature, Pels (1992) identifies four criteria for selecting key clients: (1) the possibility of increasing sales volume, (2) the capacity to develop the seller's image, (3) the know-how which it can 
transfer or help to create, and (4) the network effect, i.e., the access which a customer can provide to new markets or market segments (ibid., 6). The capacity to develop the seller's image and the network effect are phenomena closely related to the utilization of reference customers. Accordingly, two potential tasks of references are proposed: (1) developing the supplier's image and (2) aiding in gaining access to new market segments.

\section{PROPOSED TASK}

Develop supplier image

Aid in the access to new market segments

\section{REFERENCE UTILIZATION}

Selecting and negotiating with key customers that are highly esteemed by the potential buyers to ensure their willingness to be used as references.

Targeting key customers that have high reputation in the new target markets-either application markets or geographic markets.

CASE NETEZZA: MARKETING SERVICES PROVIDER EPSILON AS A KEY REFERENCE CUSTOMER

While the merits of real-time $\mathrm{BI}$ (Business Intelligence) are still debated, innovation continues and customers are responding. Also notable among those breaking the mold is Netezza, which recently introduced its first product: the Netezza Performance Server 8000 series (NPS 8000). This $\mathrm{BI}$ appliance is a rack-mountable box using off-the-shelf components and is designed to speed up data loads and query performance on very large data sets while carrying a lower price than is typical for BI systems.

Part of Netezza's low-price strategy is to use an open-source database and operating system in its box. But its secret architecture turns its cheap parts into a screaming fast datachurning engine. Sounds too good to be true? Industry analyst and Intelligent Enterprise contributing editor Philip Russom says, "Netezza already has three reference customers. So someone has confidence in it."

One of those reference customers is marketing services provider Epsilon. Its chief operating officer Bryan Kennedy was wary of the promise as well: "When we first looked at the numbers (Netezza's benchmark results), we were, frankly, skeptical." But testing it with his own large data sets convinced him it was a good deal. Kennedy already has IBM SP2 machines in place, among others, and he says that his NPS 8100 outperformed SP2, with a lower cost to boot. (Jeanette Burriesci: "Handy Appliance." Intelligent Enterprise. San Mateo: Nov.15, 2002, Vol. 5, Iss. 18; p. 10).

\section{CASE UNIGRAPHICS DESIGN SYSTEMS: USE OF A PREMIER REFERENCE SITE}

Challenging the conventions on machinery design is Pascoe Williams Ltd.'s forte. Pascoe Williams is a premier reference site for Unigraphics design systems, which means it has the latest kit in solid modeling and is used as a demonstration unit by the CAD firm. Its credits include the world's biggest welding machine and it is now involved in an intelligent turbine project, which puts it alongside names such as Alstom, the gas pipelines company Transco, the Defence Evaluation and Research Agency, and Cranfield University. 
The company has big ideas, too. "I want to develop the company using accepted best practice," says Nick Pascoe, the commercial director of Sheffield-based special purpose machinery design company: "Because we are doing important things people are taking notice of us. We've done everything right so far."

Challenging the conventions on machinery design is Pascoe's forte, and he has started to make people listen. He's on the manufacturing machinery panel of the Foresight initiative. He's got big plans for an engineering design centre working with Sheffield's universities, tapping into their research facilities and becoming a UK centre of excellence in machinery design. He's also involved in the virtual design studio project with the Open University. It becomes hard to remember, bearing in mind his grandiose plans and his confidence, that Pascoe's firm is small. Pascoe Williams is seven years old, employs 15 people, and has an annual turnover of around 1 million. (John Pullin: "Grand Designs," Professional Engineering. Bury St. Edmunds: Nov. 4, 1998. Vol. 11, Iss. 20; p. 120).

\section{Market Development Literature}

Market development strategy focuses on selling existing products in new markets or market segments. This is achieved by opening up additional geographical markets, or developing alternative versions of existing products to appeal to defined market segments not served at present (Chisnall 1995, 183). We consider opening up new geographical markets to mean a foreign market entry, and focus on issues related to this.

Entry modes can, according to "stages" models, be classified to three classes: export entry modes, contractual entry modes, and investment entry modes (Root 1987, 6). The traditional new market entry literature seeks to describe how firms decide which markets, if any, to enter, what modes of market entry are used, how the market entry process is planned, and so forth (Axelsson and Easton 1992, 220). Foreign market entry is traditionally seen primarily as a strategic decision problem and its implementation only as a secondary problem, whereas the network theory suggests that the whole process is much more complex and less structured than earlier theories and models imply (Bell 1995, 62; Blankenburg 1995, 376).

According to the network theory, the first steps of entry into the market are important. Axelsson and Johanson $(1992,233)$ found that these steps governed the subsequent entry completely by creating a chain of actor relationships. It has been noted that following domestic or international clients not only encouraged firms to begin exporting in the first place and determined the "choice" of export market(s), but also that it had a significant bearing on the market entry mode (Bell 1995, 65; Bell et al. 2001, 183). The network view to market entry suggests at least two functions for references. First, such domestic customers that have important customer/authority contacts in the entry markets should be culti- 
vated. Second, the first entry country customer should be selected, if possible, from the double perspectives of creating an esteemed reference and having a strong set of network connections in the market.

\section{PROPOSED TASK}

Use domestic customers to facilitate entry.

Create strong entry customer relationships facilitating further actor contacts.

\section{REFERENCE UTILIZATION}

Develop such domestic customerships that have a strong reputation in the target country and good linkages to potential overseas customers.

The first reference(s) can be utilized to contribute to the favorable proceeding of the entry process by selecting carefully and serving well the first reference customer(s) abroad.

CASE PRODUCTION SYSTEMS SUPPLIER: "INTERNAL REFERENCE" FACILITATING ENTRY

If a supplier of flexible productions systems for automotive sector would like to develop its network position in a global customer network, it would inevitably need a reference project. A successful project executed for a global customer's plant in, for example, Germany could be shown as an example of the supplier's capabilities, in order to get an order from a plant in the US within the same customer company. This would be a kind of "internal reference" to advance the supplier's internationalization (Håkan Håkansson and Ivan Snehota: "Developing Relationships in Business Networks," Routledge, 1995, p. 308).

CASE STEELCORR: THE CHALLENGE CREATED BY A MISSING TRACK RECORD AS A STEEL SUPPLIER

"The introduction of substantial new supplies of automotive steel . . can only drive prices down further," Peter Morici, a professor at the Robert H. Smith School of Business at the University of Maryland wrote.

"The U.S. market for automotive steel producers must lose. If SteelCorr wins the game, other U.S. steel producers must lose. Given the status as a new entrant with no track record, it is more likely that SteelCorr will be the loser." (Dennis Seid: "MDA says SteelCorr project is a winner," Knight Ridder Tribune Business News. Washington: Feb. 15, 2005, p. 1).

\section{Product Development Literature}

The role of customers has been emphasized in two essential activities in the industrial new product development process: (1) customer testing of prototypes, and (2) employing users as references during market launch (Cooper and Kleinschmidt 1986, 74; Biemans 1990). The launching process of high-technology products has been described through four stages: market preparation, targeting, positioning, and attack, each launching 
stage consisting of its own typical launching tactics (Beard and Easingwood 1996). "Market attack" tactics include, among other things, the use of reference sites, which is an important launching tactics especially for systems-type products (Beard and Easingwood 1996, 94).

Reference sites (together with customer educating methods) are used especially when planning launch into markets of revolutionary type of innovations, where high technical risk is perceived and new learning is necessary (Beard and Easingwood, 1996, 100). Frambach (1993) suggests among other things that market support can be won by legitimizing the product by publishing the names of those organizations that have already adopted the innovation. Also the participation of customers in the launching activities of innovating companies is quite common: it has been found that in the marketing of medical innovations about half of the customers participated in it (Shaw, 1985, 288; Biemans, 1992). Suppliers can even request reference customers on promoting their supplier relationship (Mantel and Rosegger, 1987).

In a nutshell, the new product development literature suggests two important roles for references: (1) involving the launching customers to promote the new product/technology actively, (2) reducing the high risk of new technology through accessible reference sites.

\section{PROPOSED TASK}

Speed up the diffusion process of a new product/technology through the "launching" customers.

Legitimate new technology by demonstrating superiority and attack the industry's existing technology paradigm

\section{REFERENCE UTILIZATION}

Develop such launch customerships where the customers are willing to promote the product/ technology.

Utilize reference sites to demonstrate the benefits of the new technology, and reference lists and promotion to legitimate it.

CASE CRANE MANUFACTURER: LACK OF THE USE OF LAUNCHING CUSTOMERS

A UK company manufacturing cranes and lorry-loaded cranes decided to extend its range by introducing a lorry-loaded cement mixer. The design-base used was French. There was no need for core testing, because the product functioned in France.

Within months of the launch, the first customers were complaining of unreliability. After investigation it was found that lorry drivers in the UK did not clear the cement mixer funnel in the same way as French lorry drivers, causing the pouring mechanism to clog. A simple case of having only in-house tests resulted in massive redesign, maintenance and compensation costs. (Michael Baker and Susan Hart: "Product Strategy and Management," Prentice Hall, 1999, p. 334). 
CASE UNUSUAL INSTALLATION: ONE REFERENCE MIGHT NOT BE ENOUGH FOR DEMONSTRATING THE SUPERIORITY OF NEW TECHNOLOGY

There is always the danger that too much weight will be placed on an early success or breakthrough and that extrapolations will be inaccurate: "We moved in just a little over a year from this new technology to a product. We got it installed in a major user's facility. What we didn't realize was how unusual this installation was. Just by chance we had encountered a bottleneck operation and our process increased output in this operation's sector by 6 per cent and also controlled pollution."

"It turned out that this product didn't work that well at all in plants of a different scale. We had started with four aces in our hand and we expected at least three next time. Instead there were none; we should have taken more seriously some of the problems we had seen in our earlier studies. What we finally learned was that our first experience of success had been anomaly." (Robert A. Burgelman \& Leonard R. Sayles: "Inside Corporate Innovation-Strategy, Structure, and Managerial Skills, The Free Press, 1986, p. 81).

The review of scientific marketing literature resulted in the identification of 17 interrelated tasks for references in business marketing. The analysis of seven autonomous but interrelated research branches of business marketing provided clear support for our initial argument of the fragmented treatment of references and their utilization in the scientific literature. This is in stark contrast to the increasing managerial relevance of referencing. In effect, the importance of referencing is increasing due to the tendencies of outsourcing, globalization of commerce, and deployment of the various modes of electronic commerce. All these trends expand global marketing, where the potential counterparts and their capabilities are often quite unknown. Thus the supplier's ability to enter new markets presumes a systematic capability of reference creation and utilization. This gap in our business marketing knowledge calls for normative theory construction for effective referencing behavior.

\section{ROLE OF REFERENCES IN BUSINESS MARKETING- A REFERENCING MODEL}

In this section we will construct a conceptual framework model for referencing behavior. We start by examining the goals and tasks assigned to references in the existing marketing practice and literature. This "received view" is then extended into a preliminary theory of referencing by constructing a framework model describing the antecedents, roles, and desired outcomes of referencing. 


\section{Received View of Supplier's Reference Utilization}

By combining the view of the utilization of references from public procurement rules, marketing textbooks, and scientific marketing literature, we produce a received view of the modes of reference usage in business marketing, depicted in Table V.

First, references can be used across all the three growth strategies of a firm mentioned in the left column. "Universal tasks," grouped into internal or external tasks, are tasks identified in the literature that references can serve, and they are independent of the growth strategies of a supplier. "Growth area specific tasks" include objectives that are related to each relevant growth strategy in the utilization of references. Only a few tasks were identified in the literature that are specifically related to either to entry to new markets or to launching a new product/technology. The "practices" column summarizes the operational ways through

TABLE V. Modes of Reference Utilization in Business Marketing

\begin{tabular}{|c|c|c|c|}
\hline $\begin{array}{c}\text { GROWTH AREA- } \\
\text { SPECIFIC } \\
\text { PURPOSE }\end{array}$ & $\begin{array}{c}\text { UNIVERSAL } \\
\text { TASKS }\end{array}$ & $\begin{array}{c}\text { GROWTH AREA- } \\
\text { SPECIFIC } \\
\text { TASKS }\end{array}$ & PRACTICES \\
\hline $\begin{array}{l}\text { Keeping present } \\
\text { and winning new } \\
\text { customers } \\
\text { (in present } \\
\text { markets with } \\
\text { present } \\
\text { products) }\end{array}$ & \multirow{3}{*}{$\begin{array}{l}\text { Internal: } \\
\text { - serve as a strategic } \\
\text { criterion in bidding } \\
\text { decisions } \\
\text { - prove the functionability } \\
\text { of technology } \\
\text { to the supplier } \\
\text { - improve sales force } \\
\text { performance } \\
\text { External: } \\
\text { win new customers } \\
\text { - aid in the access to } \\
\text { new market segments } \\
\text { get into new project } \\
\text { market } \\
\text { - break competing } \\
\text { supplier relationships } \\
\text { overcome buyer's } \\
\text { high switching costs } \\
\text { re-establish credibility } \\
\text { among old customers } \\
\text { signal service quality } \\
\text { - prove the functionability } \\
\text { of technology } \\
\text { to the buyer } \\
\text { develop the supplier's } \\
\text { image } \\
\text { enhance source } \\
\text { credibility to convince a } \\
\text { buyer about product } \\
\text { and supplier } \\
\text { performance }\end{array}$} & & \multirow{3}{*}{$\begin{array}{l}\text { - visits/demon- } \\
\text { strations in } \\
\text { reference sites } \\
\text { - articles and } \\
\text { detailed } \\
\text { descriptions of } \\
\text { similar contracts } \\
\text { in trade journals } \\
\text { - press releases } \\
\text { - reference lists } \\
\text { - promotional } \\
\text { material } \\
\text { - seminars and } \\
\text { conferences } \\
\text { - Internet } \\
\text { - requests for } \\
\text { reference } \\
\text { customers } \\
\text { to promote their } \\
\text { supplier } \\
\text { relationship }\end{array}$} \\
\hline $\begin{array}{l}\text { As effective start } \\
\text { for entry process } \\
\text { as possible } \\
\text { (with present } \\
\text { products) }\end{array}$ & & $\begin{array}{l}\text { Use domestic customers } \\
\text { to facilitate entry. } \\
\text { Create strong entry } \\
\text { customer relationships } \\
\text { facilitating further actor } \\
\text { contacts. }\end{array}$ & \\
\hline $\begin{array}{l}\text { Accelerating } \\
\text { the adoption of } \\
\text { innovation } \\
\text { (in present } \\
\text { markets with } \\
\text { new products) }\end{array}$ & & $\begin{array}{l}\text { Speed up the diffusion } \\
\text { process of a new } \\
\text { product/technology } \\
\text { through the "launching" } \\
\text { customers. } \\
\text { Legitimate new } \\
\text { technology by } \\
\text { demonstrating superiority } \\
\text { and attack the industry's } \\
\text { existing technology. }\end{array}$ & \\
\hline
\end{tabular}


which reference usage was described in the literature. All in all, our results show that the utilization of references seems to cover all the relevant growth strategies of a firm, except diversification into new markets with new products.

This 'received view' of references contains several important issues. It confirms our view that references are regarded important instruments in business marketing, but their handling in the literature is very fragmented. Although the use of references is linked to the growth strategies of the firm and is emphasized especially in the contexts of high tech marketing and project and systems marketing, the current conceptualizations do not form any comprehensive view, to say nothing of a theory, of the roles and systematic use of references. Especially the process character of reference use has been overlooked. These notions have guided the construction of our conceptual framework of reference usage.

\section{Theory of Supplier's Reference Utilization}

A good framework model requires several features: identification of the elements of the focal phenomenon, in our case references and their usage, identification of the antecedent factors influencing reference utilization, the potential outcomes of reference utilization, and identification of the relationships between the antecedents, the focal phenomenon, and its outcomes. Based on these principles we propose the Reference Model (R-model) depicted in Figure 2.

The Reference Model contains four basic building blocks; first, the contextual antecedents of a supplier's reference utilization divided into environmental factors and supplier characteristics; second, the supplier 'block' consisting of five sub-units, the growth strategy, evaluating competence, signaling decisions, operational reference practices divided into internal and external practices, and the internal outcomes of the supplier's reference utilization. The third building block is the customers who are the targets of reference utilization, divided into existing and potential customers. Potential customers are characterized according to their purchase problem characteristics, which form also situationspecific contextual antecedents influencing the supplier's reference utilization. Finally, the desired outcomes of the reference utilization form the fourth building block. In addition to these elements or blocks, the model comprises four (1-4) "referencing processes" describing the use of references between the supplier and its customers. 


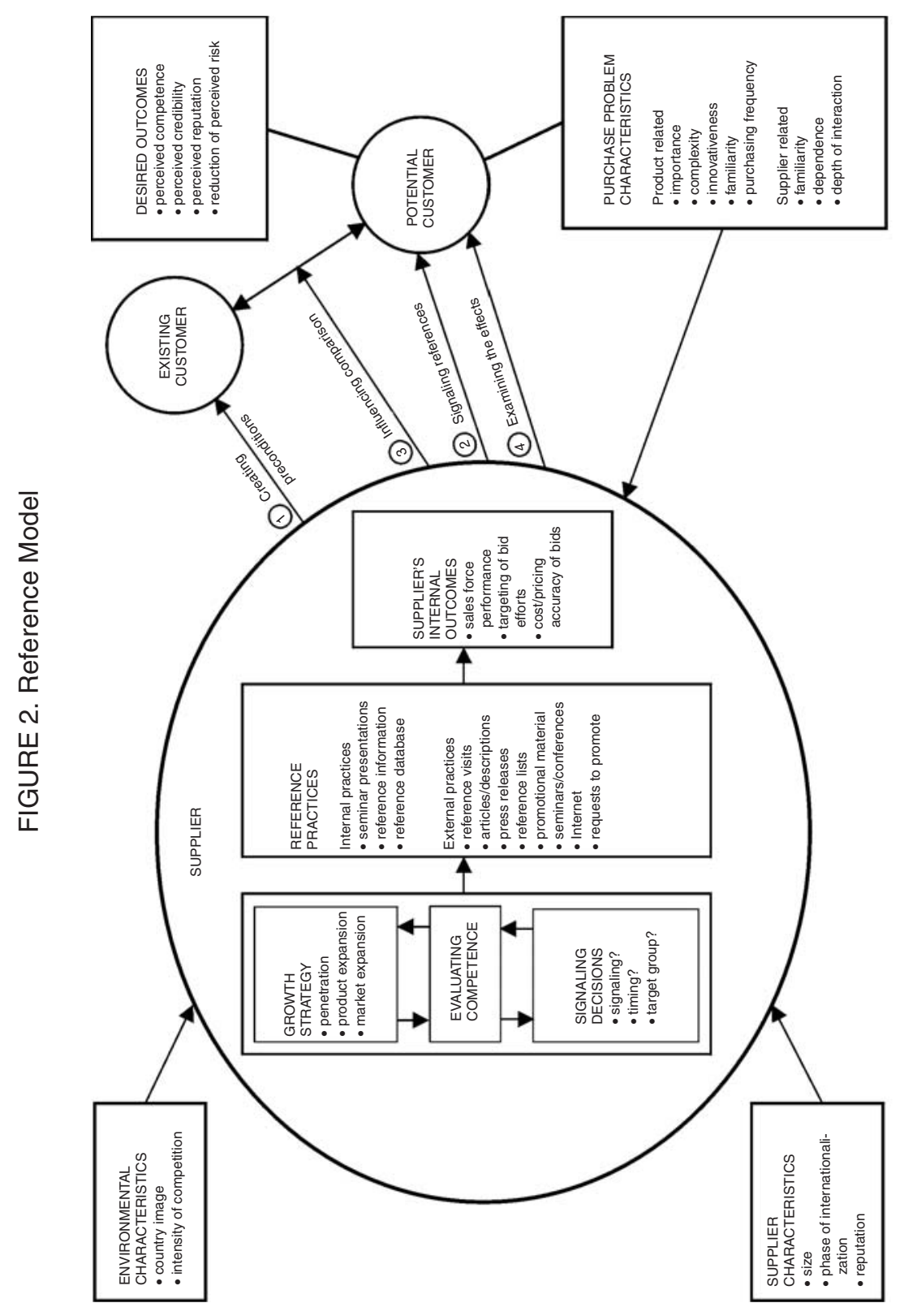


The model is described by discussing the contextual antecedents first. These are important, as they influence the relevance of the references in specific situations and thus guide the reference behavior of a supplier. In defining the contents of the contextual factors we emphasize parsimony: only those factors are included in the model, which have a reasonably strong base in the literature. Three supplier characteristics; the firm size, the phase of internationalization, and achieved reputation, are seen to influence the supplier's inherent need to use references. Larger firms that are well established in international markets and enjoy a strong reputation in their field are not so dependent on good references as small unknown companies with only a home market base. These three supplier factors can be assumed to have a more complex contingency relationship, however (Zeithaml et al. 1988). For example, even large and relatively internationalized firms do need references if they have a weak reputation in a specific product/systems field. A strong reputation can also compensate for small firm size. Yoon et al. (1993) have made a good literature review on the roles and importance of reputation.

The environmental context is described parsimoniously through only the home country image of the supplier and the intensity of competition in the target market/industry. A good country image is related to the type of industry in question. Small countries like Finland and Sweden have strong reputations in telecommunication products and in the forest industry, but are not well known for agricultural products, for example. There is also evidence that industrial products from developed countries are perceived to be superior compared to those from newly industrialized and newly industrializing countries (Chetty et al. 1999, 191). A weak or negative country image enhances the need for strong references. This is accentuated further if there exists strong competition between suppliers and if the potential customers perceive them to be relatively equal in their capabilities.

The supplier-specific factors and the external factors form contingencies that either enhance the need for references or reduce it through complex trade-off mechanisms. This influence is further complicated by the purchase problem characteristics that are related to a specific buyer. These factors are more situational than the supplier and environmental contexts. They influence a buyer's evaluation of potential suppliers and his choice criteria, among others the perceived risk. The list of purchase characteristics, classified into product-related and supplier-related factors, has been derived from the reviews of the extensive 
organizational buyer behavior literature (Möller and Laaksonen 1986; McQuiston 1989; Bunn 1993; Buvik 2001).

The importance of the product/system in question, measured through financial, end-product, and production process relevance, its complexity measured by technical and performance complexity, its relative innovativeness, familiarity for the buyer, and the purchase frequency all influence the buyer's perceived need of reference information. The higher the importance, complexity and innovativeness, and the length of commitment, the higher the buyer's perceived risk that needs to be compensated by strong reference information about the technical and commercial feasibility of the supplier's offer. The influence of product-related factors is further moderated by such supplier-related issues as supplier familiarity, dependence, and the depth of interaction needed with the supplier. Again, there is a web of complex contingencies between the listed factors. For example, when the business exchange requires great interaction intensity, the buyer generally must have strong evidence about the delivery and project management capability of the supplier if they do not know each other in advance (Möller and Rajala 1999). Positive prior experiences, i.e., familiarity, reduce the need for reference information considerably. If, however, a familiar supplier is offering a new highly innovative technological solution having longterm impact on the buyer's manufacturing process or product policy, and potential network effects on the buyer's customers, the buyer is bound to request strong referential evidence about the innovation (Ford and McDowell 1999). It is important to notice that the buyer characteristics influence strongly the type of references needed in business marketing, whereas the more general contextual factors mainly influence the more general need of references. This aspect is discussed further below, when we describe the processes through which references are used.

The supplier 'block' of the R-model consists of the supplier's interrelated evaluation of its own competence, growth strategy and signaling decisions, internal and external reference practices, and the supplier's internal outcomes. The supplier's growth strategy (penetration, product expansion, market expansion) should drive its signaling decisions. How well a supplier can estimate and plan its referencing behavior depends partly on its capability to evaluate the competencies it should signal and its ability to identify and prioritize potential key customers. The need for reference signaling is highest, as pointed out, when a relatively unknown firm tries to enter a highly risky new product field or make an entry into a culturally distant market. The current customer relationships can influence the growth decision. For example, if a new product/sys- 
tem can be "piloted" with an existing customer who is willing to act as a reference, it may impact the direction of the new product development. In the case of market entry, small innovative companies often try to follow their international customers into new market areas. In this sense, the strategy may be driven by the current reference base. Thus the supplier's reference behavior can be either strategy driven or reference driven in character, but is always dependent on the supplier's prevailing level of competence on the target segment in question. The more operational targeting of the signaling depends on the amount of a priori information that can be achieved from the potential customers in the new product field or new market.

The reference practices that the supplier can utilize are twofold: internal practices and external practices. Internal practices (seminar presentations, reference information and reference databases) are used to gain such internal outcomes as sales force training, better targeting of bidding efforts, and cost/pricing accuracy of bids. External practices list the operational repertoire available for referencing identified in the literature analysis.

The third element of the R-model covers the existing customer and the potential customer. The existing customer has two roles in the model. On the one hand, he is the reference customer who provides indirect proof of the supplier's capabilities and may even actively recommend the supplier to the potential customer. On the other hand, the existing customer can also be a target of the supplier's reference behavior. This is the case when the relationship between the supplier and the existing customer is "sleeping," i.e., there have been no any major transactions for a long time.

The description of the potential customer requires first the definition of the fourth part of the model, the desired outcomes of reference behavior. In the model these are the potential customer's perceptions of the supplier and include its perceived competence, credibility, reputation, and reduction of the perceived risk. In one sense these are the operational goals of referencing and signaling. If successfully achieved, these outcomes can have major relevance for the growth strategies of the supplier. In the model the potential customer is also characterized by how it views the buying situation (purchase problem characteristics). The perceived purchase problem characteristics influence the potential buyer's need for references especially when facing a new or relatively unfamiliar supplier. Other relevant features of the potential customer are its market position, technological position, and network position (can it provide access to other customers). The stronger these are, the more im- 
portant it is for the supplier to succeed in getting the company as a customer through effective reference behavior.

The last part of the R-model is formed by a four-phased process of referencing. At phase 1 the supplier should create preconditions for potential references by careful establishment and maintenance of its current key customer relationships. This generally requires a mutually satisfying business relationship based on trust and commitment. If successful, relational management can result in a customer base from which the supplier can choose strong references to match (1) its own growth strategy, and (2) the purchase problem characteristics of the potential new target customer. At phase 2 the chosen reference(s) are then signaled to the potential customer. The purpose is to increase the chances of a new supplier relationship by influencing positively the perceived competence, credibility, and reputation of the supplier and thus reduce the perceived risk of the buyer. If the buyer responds positively, the next phase of the process will take place. At phase 3 the supplier can try to influence the comparison standards (Anderson and Narus 1990) used by the buyer by organizing visiting to reference installations and providing documents that can influence the criteria used by the buyer in comparing alternative suppliers. Finally, at stage 4 the supplier tries to examine the effects of its referencing behavior by contacting the supplier actively. If feedback is received, it can be used for more targeted reference behavior. In a positive case, the potential customer is won and will be targeted to phase 1 activities so that it might become a passive or active reference customer. If the competition over the potential customer is lost, the supplier should analyze the causes of the negative outcome and replan its activities for the next negotiation situation. After presenting our reference model, we will conclude the paper with a discussion of the theoretical and managerial conclusions of the study.

\section{CONCLUSIONS}

Following our argument that the use of references forms an underdeveloped domain in marketing research compared to its managerial relevance, we have carried out a careful but concisely reported analysis of public procurement rules, marketing text books, and academic marketing literature concerning references and their utilization in business marketing context. The results have substantial theoretical and managerial implications. 


\section{Theoretical Implications}

The study clearly confirmed the fragmented and undeveloped nature of our understanding of how business marketers use references and how they should use them. The review results provide several notions for the development of a theory of referencing behavior.

A key observation concerns the pervasiveness of referencing behavior-references have a significant function in all major growth strategies of the firm. They facilitate the marketing of new complex offerings to present customers and winning new customers in present markets. They are essential in new market entry with current offerings, and play a key role in facilitating the introduction of new offerings containing novel technology. These functions are clearly strategic and external in the sense that the availability of competitive references conditions the potential success of a firm's chosen growth strategy. In this respect, references influence the market effectiveness of the firm and should be integrated into the strategy process of any firm that operates under conditions requiring strong referencing capability.

Our results suggest further that the relative importance of references and referencing depends on a number of interrelated contextual factors. High technological and market uncertainty increases the importance of references by enhancing the perceived risk of the potential buyers. From the technology side these uncertainties are driven by the novelty of the technology offering in question, the level of investment, and the length of commitment period involved in adopting the new solution (product or system). A related aspect is the potential network effect of the new offering. If the value of adoption depends on the number of other adopters and the speed of diffusion, the buyers can be expected to require very strong references. Besides technology, the relevance of referencing is dependent on the market and supplier specific factors. Great psychic distance between the supplier and the potential customer tends to increase the need for strong references. A weak market position of the supplier candidate, due to, e.g., smallness, periferial location, and relative anonymity in the field has the same effect. The more the factors influencing technology and market uncertainty concur, the higher the expected need of strong referencing behavior. We suggest that these general context (technology and market conditions) and supplier-specific factors influence the basic need for references, whereas the more situational buyer's characteristics provide strong heuristics for identifying the types of references needed. 
By identifying the major antecedent factors influencing the need and modes of referencing behavior, we were able to propose the reference model, which we claim is a major contribution to the understanding of the nature and use of references within business marketing. Besides the antecedents, the model identifies the supplier's internal decision domains concerning referencing (modes of growth strategy, evaluation of competence, signaling decision), sets of internal and external practices of how to carry out referencing behavior, and the supplier's internal operational referencing outcomes (more accurate bid targeting and pricing, and better sales force training and performance). The model also covers the process aspect of referencing, suggesting a set of four sub-processes through which the referencing can be carried out efficiently. The detailed referencing decisions are guided by understanding the buying situation from the perspective of the targeted customer. This takes place through analyzing a set of purchase problem characteristics.

In sum, we acknowledge that many of the proposed notions are not new as such; various aspects have been identified in such fields as organizational buying behavior, technology and diffusion of innovation studies, project and systems marketing literature, and international marketing. We contend, however, that by integrating these notions from the perspective of the utilization of references we have been able to provide a preliminary theory of referencing in the business marketing context.

\section{Managerial Implications}

We believe that most of our theoretical conclusions have direct managerial relevance, as we have deliberately tried to develop a normative theory of referencing. For example, the recognized contextual and situational factors influencing the criticality of references provide managers a tool for systematic evaluation of their need for references in different growth strategies and in different market and technology situations. In a similar way, the reference model provides managers heuristics for premeditated utilizing of references in their internal sales force training, bid planning and targeting. The identified processes provide a framework that the management can apply in the development of systematic and efficient referencing procedures.

Besides these relatively direct benefits, our results open up at least two more novel managerial issues. The first concerns the notion whether a firm pursues a 'reference-driven strategy' or a 'strategy-driven reference behavior.' In the first-mentioned mode the growth opportunities of a firm are conditioned by its current reference base. It can only try to tar- 
get new customers in such "product/market contexts" where the current reference base contains credible references. In the strategy-driven mode the management tries proactively to develop reference customers in those technology application fields and/or market areas, which the corporate targets to move into.

The development of a strong reference base poses a complex optimization problem that has also theoretical relevance. From the conceptual point of view, the reference base issue can be related to the notions of resources and customer portfolios (Zolkiewski and Turnbull 2002). The reference customer portfolio forms a resource base, the value of which is conditioned by the heterogeneity versus homogeneity of the references. A homogeneous base is strong in a narrow niche strategy, whereas a more multipurpose set of customers, in terms of technology modes/application fields and market areas, is more valuable in expanding either the application or market scope, or both. The size of the firm defining its resources obviously conditions the size of the viable base and its heterogeneity.

The second managerial problem concerns optimal referencing behavior, vis-à-vis specific target customers. The Reference Model suggests that optimal referencing presumes the ability to match the requirements set by the supplier's own growth target and its reputational position, the market conditions, and by the target customer's purchasing situation with a strong reference (matching industry, market area, and application). The finetuning of reference behavior depends also on how deep information the supplier can have about the target customer and especially how it perceives the buying situation. In an optimal case the supplier is able to match not only the reference with the customer decision criteria, but can also send in a selling team matching the customer's buying center in terms of expertise and seniority. The building of this kind of broad reference base demands both technological and functional qualities and a strong capability to manage key customer relationships. This is a challenge especially for new SME's operating in high tech business and carrying out project type business from a peripheral home base.

\section{Limitations and Directions for Future Research}

Our conclusions are based primarily on the existing conceptual material and case-type evidence on the antecedent factors, goals, practices, and outcomes of suppliers' reference behavior in business marketing. From this standpoint, the proposed reference model and the conclusions 
we have drawn have to be considered with care. They are propositions that need more robust empirical justification. We will conclude by providing some suggestions for future research.

Facing the lack of systematic research on referencing behavior, it would be useful to map and analyze the referencing practices of firms operating in fields characterized by high technological and market uncertainty. The evaluation of our proposals suggests large scale surveys in order to achieve enough variance in the identified contextual and situational factors. An important aspect is to develop valid measurements for both the referencing practices and the capabilities they require and for analyzing the outcomes of referencing. By combining a valid measurement system with large scale samples structural equation modeling can be applied for examining the validity of the postulated reference model.

The sketched approach is not very appropriate for gaining a more in-depth understanding of the proposed sub-processes of referencing. This could be achieved through case studies of firms considered to represent the best practice in reference behavior in the field.

Finally, a more novel direction would be to study referencing from the network perspective. According to the Industrial Network Approach (Ford et al. 2003) and the emerging theory of strategic nets (Möller et al. 2005), the network position that various reference customers have in their respective fields (Halinen et al. 1999), that is, the roles they are perceived to play by other network actors, and the number of weak and strong ties they have, is postulated to influence directly their relative value as references. Also this notion warrants more empirical research. To conclude, we hope that our study on the roles and relevance of referencing in business marketing will help to generate new research efforts in this field.

\section{REFERENCES}

Ahmad, I. (1990), "Decision-Support System for Modeling Bid/No-Bid Decision Problem," Journal of Construction Engineering and Management, Vol. 116, No. 4, pp. 595-608.

Ahmed, M.M. (1993), International Marketing and Purchasing of Projects: Interactions and Paradoxes, A study of Finnish Project Exports to the Arab Countries, Swedish School of Economics and Business Administration, Helsinki.

Alajoutsijärvi, K. and Pento, T. (1991), Sales Presentations to Buying Centers of Capital Goods in International Firms, University of Jyväskylä, Department of Economics and Management, Working Paper No. 115/1991. 
Anderson, J. and Narus, A. (1990), “A Model of Distributor Firm and Manufacturer Firm Working Partnerships," Journal of Marketing, Vol. 54 (January), pp. 42-58.

Ansoff, H.I. (1965), Corporate Strategy, McGraw-Hill Book Company.

Axelsson, B. and Easton, G. (1992), Industrial Networks-A New View of Reality, Routledge.

Axelsson, B. and Johanson, J. (1992), "Foreign Market Entry-The Textbook vs. the Network View," in Axelsson, B. and Easton, G. (Eds), Industrial Networks-A New View of Reality, Routledge, London, pp. 218-234.

Beard, C. and Easingwood, C. (1996), "New Product Launch," Industrial Marketing Management, 25, pp. 87-103.

Bell, J. (1995), "The Internationalization of Small Computer Software Firms-A further Challenge to 'Stage' Theories," European Journal of Marketing, Vol. 29, No. 8, pp. 60-75.

Bell, J., McNaughton, R. and Young, S. (2001), "'Born-again global' firms-An extension to the 'born global' phenomenon," Journal of International Management, 7, pp. 173-189.

Biemans, W. (1990), "The Managerial Implications of Networking," European Management Journal, Vol. 8, No. 4, December.

Biemans, W.G. (1992), Managing Innovation within Networks, Routledge, Consumer Research and Policy Series.

Bird, J. (1992), "Choosing a Consultant,” Management Today, June.

Blankenburg, D. (1995), “A Network Approach to Foreign Market Entry,” in Möller, K. and Wilson, D. (Eds), Business Marketing: An Interaction and Network Perspective, Kluwer Academic Publishers.

Bly, R.W. (1998), Business to Business Direct Marketing, second edition, NTC Business Books, United States of America.

Bonaccorsi, A., Pammolli, F. and Tani, S. (1996), "The Changing Boundaries of System Companies," International Business Review, Special Issue: Project Marketing and Systems Selling, Vol. 5, No. 6, pp. 539-560.

Bradley, F. (1995), International Marketing Strategy, Prentice-Hall International Ltd.

Brierty, E.G., Eckles, R.W. and Reeder, R.R. (1998), Business Marketing, third edition, Prentice Hall, New Jersey.

Brooks, D.G. (1978), "Bidding for the Sake of Follow-On Contracts," Journal of Marketing, January, pp. 35-38.

Bruhn, M. (2003), Relationship Marketing-Management of Customer Relationships, Pearson Education Limited.

Bunn, M.D. (1993), “Taxonomy of Buying Decision Approaches,” Journal of Marketing, Vol. 57, January, pp. 38-56.

Buvik, A. (2001), “The Industrial Purchasing Research Framework: A Comparison of Theoretical Perspectives from Micro Economics, Marketing and Organization Science," The Journal of Business and Industrial Marketing, Vol. 16, No. 6, pp. 439450.

Cardozo, R.N., Smith, D.K. and Viswanathan, M. (1988), "Identifying Key Customers for Novel Industrial Products," Journal of Product Innovation Management, 5, pp. 102-113. 
Cavusgil, T.S. and Ghauri, P.N. (1990), Doing Business in Developing Countries - Entry and Negotiation Strategies, Routledge.

Chetty, S., Dzever, S. and Quester, P. (1999), "Country of origin perception and industrial purchase decision-making in New Zealand," European Journal of Purchasing \& Supply Management, 5, pp. 185-196.

Chisnall, P.M. (1995), Strategic Business Marketing, 3rd edition, Prentice Hall.

Christensen, C. and Raynor, M. (2003), The Innovator's Solution: Creating Successful Growth, Harvard Business School Press Book.

Christopher, M., Payne, A., and Ballantyne, D. (1994), Relationship MarketingBringing Quality, Customer Service and Marketing Together, Butterworth-Heinemann Ltd. Published in association with the Chartered Institute of Marketing.

Cooper, R.G. and Kleinschmidt, E.J. (1986), "An Investigation into the New Product Process: Steps, Deficiencies, and Impact," Journal of Product Innovation Management, 3, pp. 71-85.

Cova, B. and Holstius, K. (1990), A Model for Creating Competitive Advantage in Project Business, Lappeenranta University of Technology, Research Report 28.

Cova, B., Mazet, F. and Salle, R. (1993), “Towards Flexible Anticipation: The Challenge of Project Marketing," in Baker, M.J. (Ed.), Perspectives on Marketing Management, Vol. 3, John Wiley \& Sons Ltd.

Cova, B., Mazet, F. and Salle, R. (1996), "Milieu as a Pertinent Unit of Analysis in Project Marketing," International Business Review, Special Issue: Project Marketing and Systems Selling, Vol. 5, No. 6, pp. 647-664.

Cova, B., Ghauri, P. and Salle, R. (2002), Project Marketing-Beyond Competitive Bidding, John Wiley \& Sons Ltd.

Cunningham, M.T. and Culligan, K. (1990), "Competitiveness Through Networks of Relationships in Information Technology Markets," in Ford, D. (Ed.), Understanding Business Markets-Interaction, Relationships, and Networks, The Industrial Marketing and Purchasing Group, Academic Press, pp. 508-525.

Dell, M. and Fredman, C. (2000), Direct from Dell: Strategies that Revolutionized an Industry, Harper Business.

Deutscher, T., Marshall, J. and Burgoyne, D. (1982), “The Process of Obtaining New Accounts," Industrial Marketing Management, 11, pp. 173-181.

Doz, Y., Santos J and Williamson P.J. (2001), From Global to Metanational: How Companies Win in the Knowledge Economy, Harvard Business School Press.

Dwyer, R.F., Schurr, P.H. and Oh, S. (1987), "Developing Buyer-Seller Relationships," Journal of Marketing, Vol. 51, April, pp. 11-27.

Easingwood, C. and Koustelos, A. (2000), "Marketing High Technology: Preparation, Targeting, Positioning, Execution,” Business Horizons, May-June, pp. 27-33.

EC Directive (2004), Directive 2004/18/EC of the European Parliament and of the Council of 31 March 2004 on the coordination of procedures for the award of public works contracts, public supply contracts and public service contracts.

Fisher, N. (1986), Marketing for the Construction Industry-A Practical Handbook for Consultants, Contractors, and other Professionals, Longman.

Fletcher, R., Bell, J., and McNaughton, R. (2004), International E-Business Marketing. Thomson Learning. 
Ford, D. (1984), "Buyer-Seller Relationships in International Industrial Markets," Industrial Marketing Management, Vol. 13, No. 2, pp. 101-113.

Ford, D., Gadde, L.-E, Håkansson, H., Lundgren, A., Snehota, I., Turnbull, P. and Wilson, D. (1998), Managing Business Relationships, John Wiley \& Sons, Chichester.

Ford, D. and McDowell, R. (1999), "Managing Business Relationships by Analyzing the Effects and Value of Different Actors," Industrial Marketing Management, Vol. 28, pp. 429-442.

Ford, D., Gadde, L.-E., Håkansson, H. and Snehota, I. (2003), Managing Business Relationships, second edition, John Wiley \& Sons Ltd, IMP Group.

Frambach, R.T. (1993), "An Integrated Model of Organizational Adoption and Diffusion of Innovations," European Journal of Marketing, Vol. 27, No. 5, pp. 22-41.

Gomes, Lee (2003), "How One Company Asking Hard Questions Rocks the Tech Boat," The Wall Street Journal (Eastern edition), New York, pp. B.1.

Greatorex, M., Mitchell, V.-W. and Cunliffe, R.(1992), "A Risk Analysis of Industrial Buyers: The Case of Mid-Range Computers," Journal of Marketing Management, 4, pp. 315-333.

Greener, M. (1988), The Penguin Business Dictionary, Penguin Books, New edition, Harmondsworth.

Günter, B, and Bonaccorsi, A. (1996), "Project Marketing and Systems Selling-in Search of Frameworks and Insights," International Business Review, Special Issue: Project Marketing and Systems Selling, Vol. 5, No. 6, pp. 531-538.

Hadjikhani, A. (1992), "Resource Mobilization in Package Deal Projects," in Salle, R., Spencer, R. and Valla, J., (Eds), Proceedings of the 8th IMP Conference, Lyon, France.

Hadjikhani A. (1993), Project Marketing and Changing Relationship, Working Paper 1993/10, Department of Business Studies, Uppsala University, Sweden.

Halinen, A. (1997), Relationship Marketing in Professional Services-A Study of Agency-client Dynamics in the Advertising Sector, Routledge Advances in Management and Business Studies, Routledge.

Halinen-Kaila, A., Havila, V. and Salmi, A. (1999), "From Dyadic Change to Changing Networks: An Analytical Framework," Journal of Management Studies, Vol. 36, No. 6, pp. 779-794.

Hanan, M., Cribbin, J. and Donis, J. (1978), Systems Selling Strategies, Amacom.

Hanan, M. (1995), Consultative Selling, fifth edition, Amacom.

Hannaford, W.J. (1976), "System Selling: Problems and Benefits for Buyers and Sellers," Industrial Marketing Management, 5, pp. 139-145.

Hart, N. and Hart, S. (1994), The Marketing Dictionary, 5. edition.

Hawes, J.M. and Barnhouse, S.H. (1987), "How Purchasing Agents Handle Personal Risk," Industrial Marketing Management, 16, pp. 287-293.

Heide, J.B. and Weiss, A.M. (1995), "Vendor Consideration and Switching Behavior for Buyers in High-Technology Markets," Journal of Marketing, Vol. 59, pp. 30-43.

Henthorne, T.L., LaTour, M.S. and Williams, A.J. (1993), "How Organizational Buyers Reduce Risk,” Industrial Marketing Management, 22, pp. 41-48.

Homburg, C., Workman Jr., J.P. and Jensen, O. (2002), “A Configurational Perspective on Key Account Management," Journal of Marketing, Vol. 66, pp. 38-60. 
Hutt, M.D. and Speh, T.W. (1992), Business Marketing Management-A Strategic View of Industrial and Organizational Markets, fourth edition, The Dryden Press. Hyman, D. (1994), "Time to listen to the clients," Computing Canada, Vol. 20, No. 22.

Håkansson, H. and Snehota, I. (1995), Developing Relationships in Business Networks, Routledge.

Jackson, B.B. (1985), Winning \& Keeping Industrial Customers, Lexington Books.

Jackson, R.W. and Cooper, P.D. (1988), "Unique Aspects of Marketing Industrial Services," Industrial Marketing Management, 17, pp. 111-118.

Jackson, R.W., Neidell, L.A. and Lunsford, D.A. (1995), “An Empirical Investigation of the Differences in Goods and Services as Perceived by Organizational Buyers," Industrial Marketing Management, 24, pp. 99-108.

Johnston, W.J. and Boles, J.S. (1994), "Business-to-Business Selling and Sales Force Management," in Advances in Business Marketing and Purchasing, JAI Press Inc., Vol. 6, pp. 185-219.

Kotler, P. (1988), Marketing Management; Analysis, Planning, Implementation and Control, 6th ed., Prentice Hall.

Kotler, P. (2003), Marketing Management, Eleventh edition, Prentice Hall International Editions.

Lee, M. (1989), "Contingency Approach to Strategies for Service Firms," Journal of Business Research, 19, pp. 293-301.

Lovelock, C. and Gummesson, E. (2004), “Whither Services Marketing?” Journal of Services Research, Vol. 7, No. 1 (August), pp. 20-41.

Maister, D. (1996), "Marketing to Existing Clients," in Payne, A., Christopher, M., Clark, M., and Peck, H. (Eds), Relationship Marketing for Competitive AdvantageWinning and Keeping Customers, Butterworth-Heinemann, pp. 253-263.

Mantel, S. and Rosegger, G. (1987), "The Role of Third Parties in the Diffusion of Innovations: A Survey," in Rothwell, R. and Bessant, J. (Eds), Innovation: Adaptation and Growth, Elsevier Science Publishers.

Mattsson, L.-G. (1973), "Systems Selling as a Strategy on Industrial Markets," Industrial Marketing Management, 3, pp. 107-120.

Mazet, F., Cova, B. (1992), "Project Marketing Strategies: Pell-mell or Planned," in Salle, R., Spencer, R. and Valla, J., (Eds), Proceedings of 8th IMP Conference, Lyon, France.

McDonald, M.H.B. (1988), Effective Industrial Selling, Heinemann Professional Publishing.

McKenna, R. (1986), The Regis Touch, Addison-Wesley Publishing.

McQuiston, D.H. (1989), "Novelty, Complexity, and Importance as Causal Determinants of Industrial Buyer Behavior," Journal of Marketing, Vol. 53, pp. 66-79.

Messner, J.I. (1994), An Information Framework for Evaluating International Construction Projects, A Thesis in Architectural Engineering, The Pennsylvania State University, The Graduate School, Dissertation.

Miller, G.A. (2005), Wordnet: A lexical database for the English language, Princeton University, (http://wordnet.princeton.edu).

Millman, T. and Wilson, K. (1995), "Developing Key Account Managers," in Proceedings of the Eleventh Industrial Marketing and Purchasing (IMP) Conference, University of Manchester, Manchester Business School, United Kingdom. 
Mitchell, V.-W. (1989), "Industrial Risk Reduction in the Purchase of Micro-computers by Small Businesses,” European Journal of Marketing, Vol. 24, No. 5, pp. 7-19.

Mitchell, V.-W. (1998), "Buy-phase and Buy-class Effects on Organisational Risk Perception and Reduction in Purchasing Professional Services," The Journal of Business and Industrial Marketing, Vol. 13, No. 6, pp. 461-478.

Moore, G.A. (1999), Inside the tornado: Marketing strategies from Silicon Valley's cutting edge. Harper Business Essentials.

Moore, G.A. (2002), Crossing the Chasm: Marketing and selling high-tech products to mainstream customers. Harper Business Essentials.

Morgan, R.M. and Hunt, S.D. (1994), "The Commitment-Trust Theory of Relationship Marketing," Journal of Marketing, Vol. 58, July, pp. 20-38.

Moriarty, R.T. and Kosnik, T.J. (1989), "High-Tech Marketing: Concepts, Continuity and Chance," Sloan Management Review, Vol. 30, No. 4, pp. 7-17.

Möller, K.E.K. and Laaksonen, M. (1986), Situational Dimensions and Decision Criteria in Industrial Buying: Theoretical and Empirical Analysis, Advances in Business Marketing, JAI Press Inc, Vol. 1, pp. 163-207.

Möller, K. and Rajala, A. (1999), Organizing Marketing in Industrial High-tech Firms-The Role of Internal Marketing Relationships, Industrial Marketing Management, Vol. 28, pp. 521-535.

Möller, K., Rajala, A. and Svahn, S. (2005) Strategic Business Nets-Their Type and Management, Journal of Business Research, Vol. 58, pp. 1274-1284.

Möller, K. and Törrönen, P. (2003), "Business Suppliers' Value Creation Potential - A Capability-based Analysis," Industrial Marketing Management, Vol. 32, pp. 109118.

NASA Source Evaluation. NFS subpart 1870.3 (an Internet version of NASA FAR Supplement (NFS) (48 CFR 1870.303). http://venus.hq.nasa.gov/office/procurement/regs/n70.3.htm.

Ojasalo, J. (2001), "Key account management at company and individual levels in business-to-business relationships," Journal of Business \& Industrial Marketing, Vol. 16, No. 3, pp. 199-216.

Paliwoda, S.J. and Bonaccorsi, A.J. (1993), "Systems Selling in the Aircraft Industry," Industrial Marketing Management, 22, pp. 155-160.

Parasuraman, A. (1981), “The Relative Importance of Industrial Promotion Tools," Industrial Marketing Management, Vol. 10, No. 4, pp. 277-281.

Parasuraman, A. and Varadarajan, P. (1988), "Future Strategic Emphases in Service Versus Goods Business," The Journal of Services Marketing, Vol. 2, No. 4, Fall, pp. 57-66.

Pardo, C., Salle, R. and Spencer, R. (1995), “The Key Accountization of the Firm,” Industrial Marketing Management, 22, pp. 123-134.

Payne, A., Christopher, M., Clark, M. and Peck, H. (1996), Relationship Marketing for Competitive Advantage, Butterworth-Heinemann.

Pels, J. (1992), "Identification and Management of Key Clients," European Journal of Marketing, Vol. 26, No. 5, pp. 5-21.

Peterson, R.T. (1990), “Sales Managers' Evaluation of the Effectiveness of Various Sales Training Methods," in Enhancing Knowledge Development in Marketing, AMA Educators' Proceedings, Volume 1. 
Pickett, J.P. (2000), The American Heritage Dictionary of the English Language, fourth edition, Boston: Houghton Mifflin Company.

Puto, C.P., Patton, W.E., King, R.H. (1985), "Risk Handling Strategies in Industrial Vendor Selection Decisions," Journal of Marketing, Vol. 49, pp. 89-98.

Ravald, A. and Grönroos, C. (1996), "The Value Concept and Relationship Marketing," European Journal of Marketing, Vol. 30, No. 2, pp. 19-30.

Riggs, H.E. (1983), Managing High-Technology Companies, Van Nostrand Reinhold.

Root, F.R. (1987), Entry Strategies for International Markets, Lexington Books.

Rosen, B. (1994), "Looking for a few good vendors," Legal Assistant Today, Vol. 11, No. 5.

Shaw, B. (1985), "The Role of the Integration Between the User and the Manufacturer in Medical Equipment Innovation,” R \& D Management, Vol. 15, No. 4, pp. 283-292.

Shaw, J., Giglierano, J., Kallis, J. (1989), "Marketing Complex Technical Products: The Importance of Intangible Attributes," Industrial Marketing Management, 18, pp. 45-53.

Simpson, J. and Weiner, E. (1989) (Eds), The Oxford English Dictionary, second edition, Vol. XIII, Quemadero-Roaver, Clarendon Press, Oxford.

Slatter, S.St.P. (1987), “The Salesman's Job in Competitive Bidding Situations," Industrial Marketing Management, 16, pp. 201-205.

Slatter, S.St.P. (1990), "Strategic Marketing Variables Under Conditions of Competitive Bidding," Strategic Management Journal, Vol. 11, pp. 309-317.

Smilor, R.W. (Ed) (1989), Customer Driven Marketing: Lessons from Entrepreneurial Technology Companies, Lexington Books.

Stewart, R.D. and Stewart A.L. (1984), Proposal Preparation, John Wiley \& Sons.

Timmers, P. (2000), Electronic Commerce-Strategies and Models for Business-toBusiness Trading, John Wiley \& Sons Ltd, England.

Turnbull, P., W. (1979), "Roles of Personal Contacts in Industrial Export Marketing," in Ford, D. (Ed.), Understanding Business Markets-Interaction, Relationships, and Networks, The Industrial Marketing and Purchasing Group, Academic Press, pp. 78-86.

Usunier, J.-C. (1996), Marketing Across Cultures, second edition, Prentice Hall Europe, London.

Vargo, S.L. and Lusch, R.F. (2004a), Evolving to a New Dominant Logic for Marketing. Journal of Marketing, 68 (1), pp. 1-17.

Vargo, S.L. and Lusch, R.F. (2004b), “The Four Service Marketing Myths,” Journal of Service Research, Vol. 6, No. 4 (May), pp. 324-335.

Wall, Robert (2004), "Cyclone Forming," Aviation Week \& Space Technology, New York, Vol. 161, No. 5, pp. 33.

Wolf, M. (2004), Why Globalization Works, Yale University Press.

World Bank (1993), Standard Prequalification Documents, Procurement of WorksMajor Equipment and Industrial Installations, The World Bank Washington, D.C., April 1993.

World Bank (1995), Guidelines: Procurement under IBRD Loans and IDA Credits, The World Bank Washington, D.C., January 1995. 
Yoon, E., Guffey, H.J. and Kijewski, V. (1993), "The Effects of Information and Company Reputation on Intentions to Buy a Business Service," Journal of Business Research, Vol. 27, pp. 215-228.

Zaltman, G., Pinson, C.R.A. and Angelmar, R. (1973), Metatheory and Consumer Research, Holt, Rinehart and Winston Inc.

Zeithaml, V.A., Varadarajan, P. "Rajan” and Zeithaml, C.P. (1988), "The Contingency Approach: Its Foundations and Relevance to Theory Building and Research in Marketing," European Journal of Marketing, Vol. 22, No. 7, pp. 37-64.

Zeithaml, V.A. and Bitner, M.J. (1996), Services Marketing, The McGraw-Hill Companies Inc.

Zolkiewski, J. and Turnbull, P. (2002), "Do Relationship Portfolios and Networks Provide the Key to Successful Relationship Management?” The Journal of Business and Industrial Marketing, Vol. 17, No. 7, pp. 575-597.

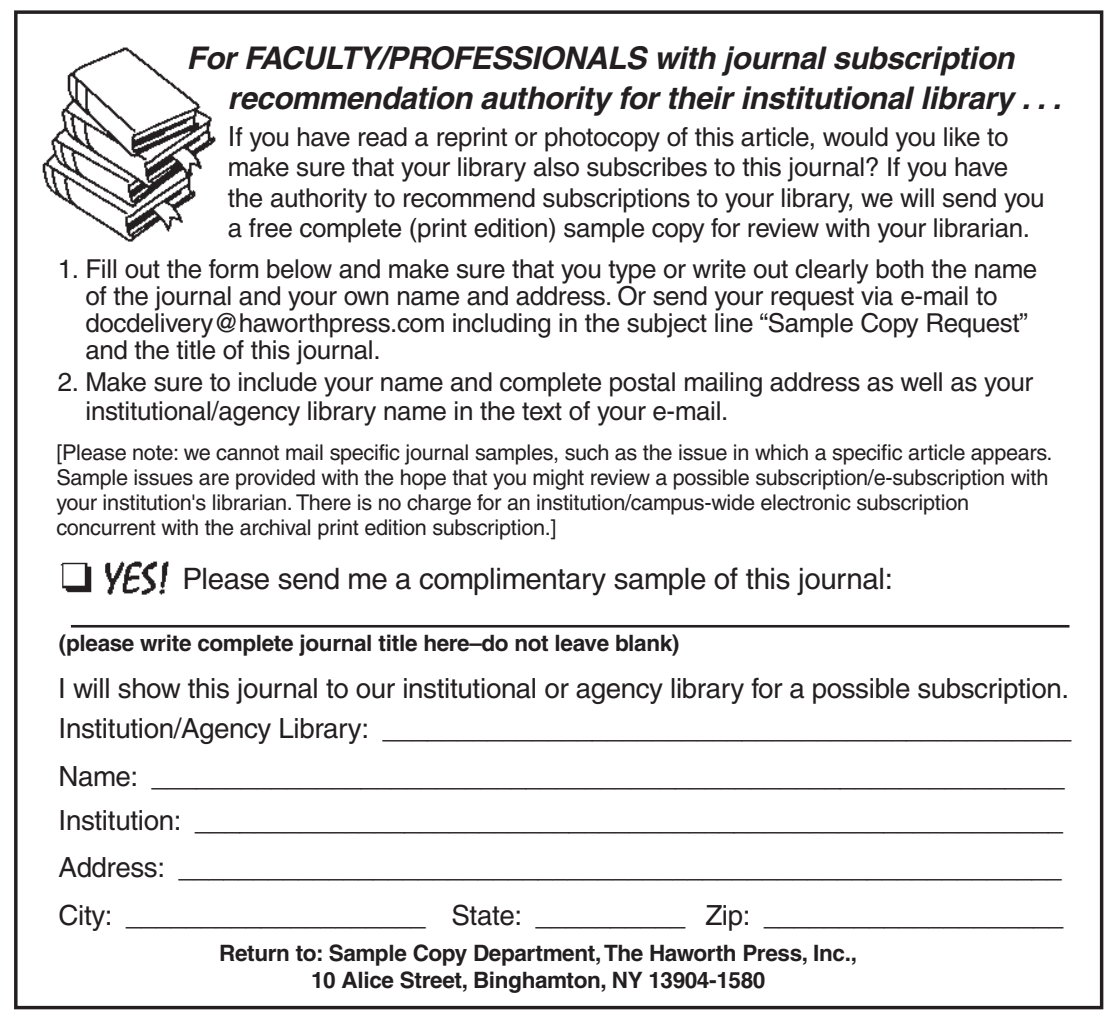




\section{EXECUTIVE SUMMARY}

The use of references is a common marketing practice in business marketing. Therefore, the idea that references play an important part in business marketing is generally taken for granted. Most issues of business magazines like BusinessWeek, Forbes, and Fortune contain cases on the essential role of references in such strategic actions as launching new products and entering new markets, as well as in enhancing a company's competitive position in the industry. There is, however, very little reported academic research on references.

There are several trends that enhance the importance of referencing and the capability of firms to utilize references in a strategic manner: the intensifying technological complexity, high knowledge intensity, and systemic quality of the offerings and production systems of today's industries. These characteristics, together with the shortening of technological life cycles, encompass a high level of technological and market uncertainty. Another trend is the rapid globalization of most high tech industries, where companies have to be able to convince new customers from different cultural backgrounds about the reliability of their offerings, their delivery and continuous performance. Finally, the Internet can be used to establish direct contacts over a widely dispersed set of customers. All these tendencies increase the relevance of references and referencing in business marketing.

A frequently expressed goal of using references is reducing the perceived risk of a potential buyer facing the choice of a new supplier or product, by communicating the credibility of the supplier. For that purpose, managers generally see successful deliveries of equipment, services, or projects to customers as references. A supplier can utilize its references in various ways through reference lists, articles in trade journals, press releases, reference visits, promotional material, seminars, and the Internet.

Deliveries are often compiled to various types of reference lists that are attached to offers to potential customers. These reference lists are sent to the potential customers in the hope that a positive impression will be conveyed about the supplier and its product/service attributes. The importance of specific supplier characteristics and product and technology attributes is reflected in the utilization of different types of reference lists: application segment specific lists, product specific lists, technology specific lists, and country/region specific lists. Today, selected references are often also shown in companies' Internet home 
pages in the form of names of reference customers, project references or showcases among others.

In the present study major deliveries and the names of existing customers are considered and used as references. For that purpose the following definition of reference is presented: "An indirect proof, based on some practical or concrete evidence, like product, service or systems delivery, of a supplier's capability of delivery."

In spite of the importance of references in practice, there is little reported academic research on references. Recognizing the gap between the presumed managerial relevance of references and their limited theoretical treatment in business marketing research and literature, the basic objective of this study is to propose a preliminary theory of business marketers' referencing behavior.

We have pursued our goal through an extensive literature analysis covering the reference practices identified first in institutional authorities' (European Community, World Bank, NASA) public procurement rules, then in marketing textbooks, and finally in scientific marketing literature. The review of scientific literature resulted in 17 interrelated tasks for references in business marketing. The study clearly confirmed the fragmented nature of our understanding of how business marketers use references, and how they should use them.

On the basis of the literature review we constructed a reference model. It contains four basic building blocks; first, the contextual antecedents of a supplier's reference utilization divided into environmental factors and supplier characteristics; second, a supplier 'block' consisting of five sub-units, the growth strategy, evaluating competence, signaling decisions, operational reference practices divided into internal and external practices, and the internal outcomes of the supplier's reference utilization. The third building block is the customers who are the targets of reference utilization, divided into existing and potential customers. Potential customers are characterized according to their purchase problem characteristics, which form also situationspecific contextual antecedents influencing the supplier's reference utilization. Finally, the desired outcomes of the reference utilization form the fourth building block. In addition to these elements or blocks, the model comprises four "referencing processes" (creating preconditions, signaling references, influencing comparison standards and examining the effects) describing the use of references between the supplier and its customers.

The recognized contextual and situational factors influencing the criticality of references provide managers a tool for systematic evaluation of 
their need for references in different growth strategies and in different market and technology situations. In a similar way, the reference model provides managers heuristics for premeditated utilizing of references in their internal sales force training, bid planning and targeting. The identified processes provide a framework that the management can apply in the development of systematic and efficient referencing procedures.

Besides these relatively direct benefits, our results open up at least two more novel managerial issues. The first concerns the notion whether $a$ firm pursues a 'reference-driven strategy' or a 'strategy-driven reference behavior.' In the first-mentioned mode the growth opportunities of a firm are conditioned by its current reference base. It can only try to target new customers in such "product/market contexts" where the current reference base contains credible references. In the strategy-driven mode the management tries proactively to develop reference customers in those technology application fields and/or market areas which the corporate targets to move into.

The reference customer portfolio forms a resource base, the value of which is conditioned by the heterogeneity versus homogeneity of the references. A homogeneous base is strong in a narrow niche strategy, whereas a more multipurpose set of customers, in terms of technology modes/application fields and market areas, is more valuable in expanding either the application or market scope, or both. The size of the firm, which defines its resources, obviously conditions the size of the viable base and its heterogeneity.

The second managerial problem concerns optimal referencing behavior vis-à-vis specific target customers. The reference model suggests that optimal referencing presumes the ability to match the requirements set by the supplier's own growth target and its reputational position, the market conditions, and by the target customer's purchasing situation with a strong reference (matching industry, market area, and application). The finetuning of reference behavior depends also on how much information the supplier can have about the target customer and especially how it perceives the buying situation. In an optimal case the supplier is able to match not only the reference with the customer decision criteria, but can also send in a selling team matching the customer's buying center in terms of expertise and seniority.

The building of this kind of broad reference base demands both technological and functional qualities and a strong capability to manage key customer relationships. This is a challenge especially for new SMEs operating in high tech business and carrying out project type business from a peripheral home base. 